University of Nebraska - Lincoln

DigitalCommons@University of Nebraska - Lincoln

\title{
An Analysis of Simulated Long-Term Soil Moisture Data for Three Land Uses under Contrasting Hydroclimatic Conditions in the Northern Great Plains
}

\author{
Rezaul Mamood \\ University of Nebraska - Lincoln, rmahmood2@unl.edu \\ Kenneth G. Hubbard \\ University of Nebraska - Lincoln
}

Follow this and additional works at: https://digitalcommons.unl.edu/hprccpubs

Part of the Atmospheric Sciences Commons, Climate Commons, Environmental Indicators and Impact Assessment Commons, Environmental Monitoring Commons, Fresh Water Studies Commons, Hydrology Commons, Meteorology Commons, Natural Resources Management and Policy Commons, Sustainability Commons, and the Water Resource Management Commons

Mamood, Rezaul and Hubbard, Kenneth G., "An Analysis of Simulated Long-Term Soil Moisture Data for Three Land Uses under Contrasting Hydroclimatic Conditions in the Northern Great Plains" (2004). HPRCC Personnel Publications. 27. https://digitalcommons.unl.edu/hprccpubs/27

This Article is brought to you for free and open access by the High Plains Regional Climate Center at DigitalCommons@University of Nebraska - Lincoln. It has been accepted for inclusion in HPRCC Personnel Publications by an authorized administrator of DigitalCommons@University of Nebraska - Lincoln. 


\title{
An Analysis of Simulated Long-Term Soil Moisture Data for Three Land Uses under Contrasting Hydroclimatic Conditions in the Northern Great Plains
}

\author{
Rezaul Mahmood \\ Department of Geography and Geology, and Kentucky Climate Center, Western Kentucky University, Bowling Green, Kentucky \\ KenNeth G. HubBard \\ High Plains Regional Climate Center, School of Natural Resource Sciences, University of Nebraska at Lincoln, Lincoln, Nebraska
}

(Manuscript received 13 December 2002, in final form 10 July 2003)

\begin{abstract}
Soil moisture (SM) plays an important role in land surface and atmosphere interactions. It modifies energy balance near the surface and the rate of water cycling between land and atmosphere. The lack of observed SM data prohibits understanding of SM variations at climate scales under varying land uses. However, with simulation models it is possible to develop a long-term SM dataset and study these issues.

In this paper a water balance model is used to provide a quantitative assessment of SM climatologies for three land uses, namely, irrigated corn, rain-fed corn, and grass, grown under three hydroclimatic regimes in Nebraska. These regimes are stops along an east-west decreasing precipitation gradient of the Great Plains. The simulated SM climatologies are provided for the root zone as a whole and for the five layers of the soil profile to a depth of $1.2 \mathrm{~m}$. As expected, the soil water content in the root zone of irrigated corn was higher than rainfed corn or grass. The lowest levels of soil water depletion were found under rain-fed corn cultivation due to its complete reliance on naturally available SM. The annual total evapotranspiration (ET) was 34\% and 36\% higher for irrigated corn than for rain-fed corn and grass, respectively. The study suggests that due to interannual variability the SM variability is higher for deeper depths, as compared to near-surface depths. Growing season SM depletion and prevailing soil water content at various depths of the soil profile varies with crops, soils, and prevailing hydroclimatic conditions.

The results show that land use affects the magnitude of SM variability at all time scales. At a daily temporal scale, SM variability is less under irrigated land use and sharply increases under rain-fed land uses. At the monthly scale, SM variability largely follows the trend of the daily time scale. Year-to-year SM variability is significant. Extremely dry or wet conditions enhance and reduce, respectively, the forcing of land use on SM variability at an annual time scale. Thus, large-scale interannual climate variations and land use jointly affect SM variability at this scale.
\end{abstract}

\section{Introduction}

Soil moisture (SM) is an important mediator in the hydrologic cycle that converts a time series characterized by white noise (precipitation) into a time series characterized by red noise (soil moisture) (Delworth and Manabe 1988; Vinnikov and Yeserkepova 1991). Reliable soil moisture sensors have recently become available but, due to the lack of long-term soil water data, it is difficult to determine how soil moisture varies historically (Georgakakos et al. 1995). If we can estimate soil moisture reliably from long-term climate data, then the role of soil moisture in regional and global water cycles can be better understood. Two decades ago

Corresponding author address: Dr. Rezaul Mahmood, Department of Geography and Geology, and Kentucky Climate Center, Western Kentucky University, Bowling Green, KY 42101.

E-mail: rezaul.mahmood@wku.edu
Schmugge et al. (1980) discussed the importance of such SM estimates for hydroclimatological studies in the absence of observed data. Recently, Crawford et al. (2000) suggested that SM parameterizations in numerical weather prediction models are overly simplified. They have also noted that, for example, the Eta Model (Black 1994) of the National Centers for Environmental Prediction (NCEP) and the fifth-generation Pennsylvania State University-National Center for Atmospheric Research (PSU-NCAR) Mesoscale Model (MM5; Dudhia 1993) use a climatological SM value to establish initial conditions.

In this paper we use data from a soil moisture process model to reconstruct and investigate past soil moisture "pseudo" climatologies for selected locations (Fig. 1) and for three land uses of the northern Great Plains (NGP). This study simulates and analyzes SM for multiple land uses for five depths up to $1.2 \mathrm{~m}$ at climate scales. This paper also investigates climatic variability 


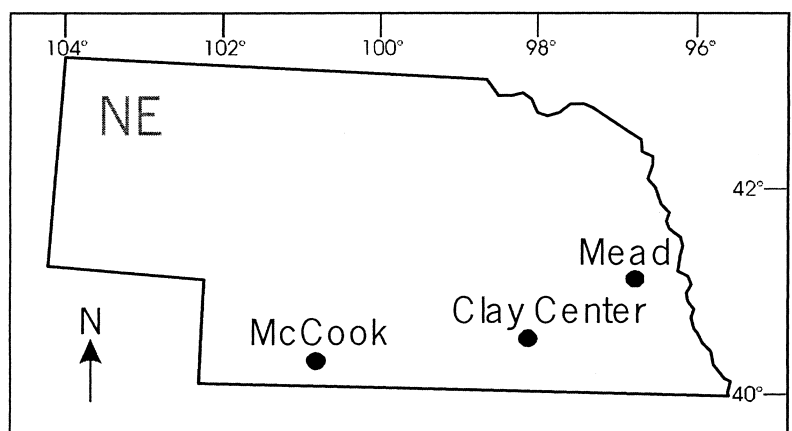

FIG. 1. Location of model application sites.

of SM at multitemporal scales under contrasting land uses and assesses forcing of land use at these scales. This study is part of our ongoing effort to build and analyze an SM dataset for the NGP. We also raise the possibility that this model applied on a grid-by-grid basis could be used to initialize mesoscale meteorological and climatological models. The SM model was applied and successfully validated by Robinson and Hubbard (1990, RH hereafter), and is currently offered as a tool for irrigation scheduling in the Northern Great Plains. In previous studies, the SM model was applied to investigate the impacts of land use change on SM and evapotranspiration (ET) in the NGP (Mahmood and Hubbard 2002a), the role of irrigation on near-surface temperature records (Mahmood et al. 2002), the partitioning of energy (Mahmood et al. 2001), and the timing of precipitation in drought assessment (Meyer et al. 1993a,b). A sensitivity analysis of the SM and ET for soils heterogeneity is also completed (Mahmood and Hubbard 2003).

The RH model validation was completed for five predominant and representative land uses in the Great Plains at nine locations extending from eastern to western Nebraska (Robinson and Hubbard 1990). The validation was also provided for six soils layers up to the depth of $1.8 \mathrm{~m}$. Land uses included in the validation were grass, corn, wheat, sorghum, and soybeans. The validation sites are representative of the east-west hydroclimatic gradient of the Great Plains and included several climatological zones. The data were collected over two growing seasons (April through September and/or October) in 1986 and 1987. This was already an improvement over Cherkauer and Lettenmaier (1999), for which the variable infiltration capacity (VIC) model validation was completed for one location, and also over Crawford et al. (2000), where validation was conducted for 1 month of data for grass only (July 1997). In addition, validation of the $\mathrm{RH}$ model was completed over a larger area than the previous studies (cf. Crawford et al. 2000). Our assessment shows that performance of the RH model is also superior to many land surface schemes (LSSs). Section 3 of this paper includes a detailed discussion on the RH model performance. For

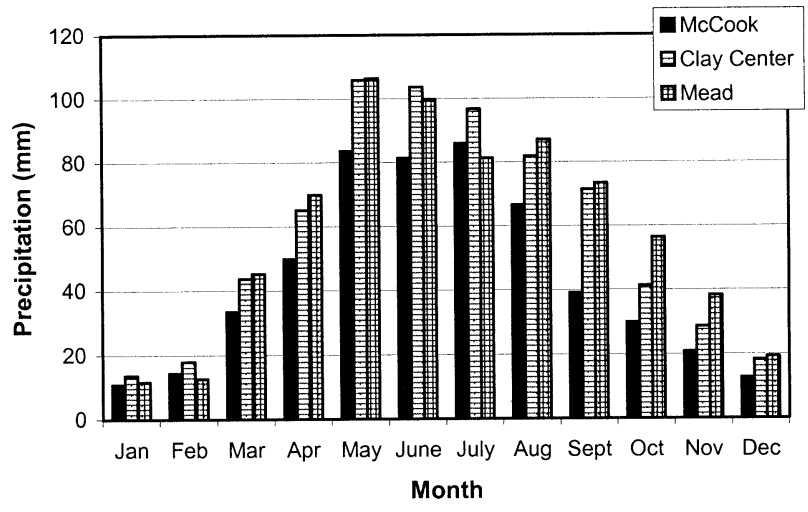

FIG. 2. Mean monthly precipitation at three locations.

additional information on the model and its validation, the authors urge readers to consult Robinson and Hubbard (1990), Camargo (1993), and Camargo et al. (1994).

For this study, as noted above, the model is applied to three predominant land uses, namely, irrigated and rain-fed corn, and rain-fed grass. Irrigated corn has a longer growing season (May through late September and/or early October) compared to rain-fed corn (May through late August and/or early September) and grass (May-August). Water consumption also varies according to land use and differences in plant life cycles. Application of water for irrigated corn notably modifies natural root zone SM and hydrology (Mahmood and Hubbard 2002a). Thus, rain-fed and irrigated land uses with the same plants provide significantly different hydrological conditions. The RH model applications were repeated for three sites in Nebraska, representing a decreasing precipitation gradient from east to west, typical of the Great Plains (Fig. 2). The model estimates of soil water are for the top five layers for a period from 1982 to 1999 . The five layers represented in the model are from $0-2.5,2.5-30.5,30.5-61,61-91.5$, and 91.5-122 $\mathrm{cm}$, respectively. Vegetation- and crop-specific growing degree days (GDDs) were used for realistic representation of plant growth. GDD is calculated to determine crop phenology, which is associated with the potential for water consumption at different growth stages.

\section{Background}

A significant number of research projects have been undertaken and completed over the last two decades, focusing on the relationship between SM and climate. Hong and Pan (2000) reported a strong positive feedback between initial SM and simulated seasonal precipitation. The simulations were conducted by using the NCEP Regional Spectral Model (RSM). Model simulations show that soil water storage eventually effects moisture distribution within the boundary layer atmosphere and its structure (Hong and Pan 2000). Wang 
and Kumar (1998) suggested that interannual variations of SM may play a role in seasonal predictability of surface climate anomalies. They have found a strong correlation between SM and surface temperature anomalies. Dirmeyer $(1999,2000)$ also noted that incorrect SM inputs reduced the accuracy of simulated precipitation anomalies. Huang et al. (1996) reported from their study that SM is a better predictor of temperature over large areas during the summer season, compared to precipitation. A number of sensitivity studies for several LSSs were conducted under the Global Soil Wetness Project (GSWP) and the Project for Intercomparison of Land-Surface Parameterization Schemes (PILPS) (e.g., Qu et al. 1998; Morrill et al. 1999; Pitman et al. 1999; Dirmeyer 1999). PILPS undertook a phase-by-phase approach to compare and improve estimates of water and energy flux by the LSSs (Chen et al. 1997; Wood et al. 1998; Liang et al. 1998; Lohmann et al. 1998). Lohmann et al. (1998) noted that simulated changes in mean seasonal cycles of soil moisture storage agreed qualitatively with observations. In other words, it will be difficult for researchers and forecasters to confidently quantify soil moisture using these models.

To overcome some of the uncertainties in the design of LSSs, and to increase the accuracy of the estimated flux and storage of energy and water and to produce global SM data, a new project, the Land Data Assimilation System (LDAS) was undertaken (Mitchell et al. 2000). The success of this project remains to be seen. The Atmospheric Model Intercomparison Project (AMIP) reported that none of the AMIP models captured interannual variations in SM (Robock et al. 1998). The SM estimates provided by the revised AMIP models also show no improvement in capturing seasonal variations in SM (Srinivasan et al. 2000). The GSWP used $10 \mathrm{LSSs}$ to produce global SM data. It is noted that none of the models produced satisfactory estimates of SM for any regions (Entin et al. 1999). Robock et al. (2000) made a similar observation. Entin et al. (1999) observed that model biases vary from region to region. Therefore, a simple approach would not be sufficient (Entin et al. 1999). Entin et al. (1999) suggest that future research projects should include experiments with a longer time scale.

Hollinger and Isard (1994) analyzed a measured SM dataset from Illinois. The data were collected from 17 sites in Illinois and the SM was measured biweekly from March through September, and monthly during the winter up to a depth of $2 \mathrm{~m}$. They found latitudinal and longitudinal gradients of SM variations related to season and reported variations of water-holding capacity due to soil texture. Vinnikov and Yeserkepova (1991) analyzed measured SM data from the former Soviet Union for the period of 1972-85. The data used in this study were collected from a depth of $1 \mathrm{~m}$. For warm months the data were measured 3 times a month, and for cold months measurements were made once a month. Vinnikov and Yeserkepova (1991) found a positive linear trend in SM over a number of regions in response to increasing regional precipitation. They also noted that measured SM data did not agree well with GCM-simulated estimates. Entin et al. (2000) estimated temporal and spatial scales of SM variations, using measured data from China, Mongolia, the Soviet Union (Vinnikov and Yeserkepova 1991), Illinois (Hollinger and Isard 1994), and Iowa. Wittrock and Ripley (1999) used a Canadian dataset to determine the regional and spatial pattern of SM during autumn. The SM data used in the above studies were collected at various time scales, including every 10 days, once a month, and once a year (e.g., Wittrock and Ripley 1999). In the recent past, Nijssen et al. (2001) and Maurer et al. (2002) developed an SM dataset for the globe and the conterminous United States, which can be used by various climate models. The Maurer et al. (2002) SM dataset is used by Maurer and Lettenmaier (2003) to forecast runoff in the Mississippi basin and found promising results.

It is apparent from the above that the absence of longterm SM data with high temporal measurement density has precluded meteorological and climatic interpretations. The unavailability of data also has prevented a better grasp of how SM behaves at different depths within the top $2 \mathrm{~m}$ of the soil profile. A lack of simultaneous assessment of SM variations under a number of prevalent land use/land cover types has been a hurdle to understanding linkages to climate. In addition, insufficient discussion on SM variability at different temporal scales under multiple land uses has prevented a more realistic representation of landscape. This study provides daily SM estimates for five layers in the soil profile for three land uses and SM variability at different time scales under different land uses. One of the advantages of using the RH model lies in the fact that it is finetuned to local (the NGP) land use and hydroclimatic conditions. In addition, due to large-scale modification of natural grasslands to agricultural land use in the Great Plains, it is essential that we investigate SM of croplands along with grasslands. Furthermore, Qiu et al. (2001) emphasized that the relationship between land use and soil moisture needs to be investigated under a variety of conditions. The present study addresses this concern.

GCIP (2000), Leese (2000), and Leese et al. (2001) noted that development of long-term soil moisture datasets for climatological studies and that understanding the role of land memory processes in predictability is a high priority for future research. The United States Global Change Research Program (USGCRP) recognizes that variations in the water cycle at climatological scales are a key research issue for the future (USGCRP 2001). Our long-term goal is to address these objectives of the USGCRP. Note that this study will be conducted within a Global Energy and Water Cycle Experiment (GEWEX) Americas Prediction Project (GAPP) area (Mississippi watershed). 
TABLE 1. Soil water measurements by location and land use. (Source: Robinson and Hubbard 1990.)

\begin{tabular}{|c|c|c|c|c|}
\hline Site & Year & Land use & $\begin{array}{c}\text { Days with } \\
\text { measured water } \\
(\#)\end{array}$ & Dates of measurement \\
\hline \multirow[t]{2}{*}{ North Platte, NE } & 1986 & Corn & 13 & Jun: 4, 11, 18, 25; Jul: 2, 9, 16, 23, 30: Aug: 13, 20, 27; Sep: 3 \\
\hline & & Wheat & 12 & Apr: 23, 30; May: 7, 14, 21, 28; Jun: 4, 11, 18, 25; Jul: 2, 9 \\
\hline \multirow{4}{*}{ North Platte, NE } & 1987 & Corn & 12 & Jun: $2,11,17$; Jul: 7, 14, 21, 27; Aug: 4, 11, 18; Sep: 1,8 \\
\hline & & Wheat & 4 & May: 26; Jun: 2, 11, 17 \\
\hline & & Sorghum & 12 & Jun: 2 , 10, 17; Jul: 7, 14, 21, 27; Aug: 4, 11, 18; Sep: 1,8 \\
\hline & & Soybean & 12 & Jun: $2,10,17$; Jul: $7,14,21,28:$ Aug: 4, 11, 18; Sep: 1,8 \\
\hline \multirow[t]{4}{*}{ Clay Center, NE } & 1987 & Corn & 8 & Jun: 30; Jul: 7, 21, 30; Aug: 6, 21, 27; Sep: 30 \\
\hline & & Wheat & 9 & Apr: 23, 29; May; 7, 15, 29; Jun: 9, 18, 30; Jul: 7 \\
\hline & & Sorghum & 8 & Jun: 30; Jul: 7, 21, 30; Aug: 6, 21, 27; Sep: 30 \\
\hline & & Soybean & 8 & Jun: 30; Jul: 7, 22, 30; Aug: 6, 21, 27; Sep: 30 \\
\hline \multirow[t]{3}{*}{ Concord, NE } & 1987 & Corn & 11 & Jun: 11 , 25; Jul: 1, 9, 16, 23, 30; Aug: 5, 14; Sep: 11, 28 \\
\hline & & Sorghum & 9 & Jul: $1,8,16,23,30 ;$ Aug: 5, 14; Sep: 11, 28 \\
\hline & & Soybean & 11 & Jun: 11, 25, Jul: 1, 9, 16, 23, 30; Aug: 5, 14; Sep: 11, 28 \\
\hline \multirow[t]{2}{*}{ Mead, NE } & 1986 & Wheat & 5 & May 14,$30 ;$ Jun: $13 ;$ Jul: 2,16 \\
\hline & & Soybean & 5 & Jun: 6,$13 ;$ Jul: $2,17,29$ \\
\hline Brookings, SD & 1987 & Corn & 4 & Jun: 29; Jul: 13; Aug: 6, 26 \\
\hline Chamberlin, SD & 1987 & Corn & 5 & Jul: 1, 14, 30; Aug: 20; Sep: 14 \\
\hline Wheatland, WY & 1986 & Wheat & 8 & May: 30; Jun: 15, 30; Jul: 14, 28; Aug: 11, 26; Sep: 8 \\
\hline Sidney, NE & 1987 & Wheat & 8 & May: 27; Jun: $3,11,18,26$; Jul: $2,9,16$ \\
\hline Chugwater, WY & 1987 & Grass & 10 & May: 19; Jun: $2,10,16,23,30 ;$ Jul: $7,14,21,28$ \\
\hline
\end{tabular}

\section{RH SM model and its performance evaluation}

The RH SM model can be presented as follows:

$$
\partial S / \partial t=P+I-\mathrm{ET}-R_{0}-D_{r},
$$

where $S(\mathrm{~cm})$ is soil water in the root zone, $t$ is time, $P(\mathrm{~mm})$ is precipitation, $I(\mathrm{~mm})$ is irrigation, ET $(\mathrm{mm})$ is actual evapotranspiration, $R_{0}(\mathrm{~mm})$ is runoff, and $D_{r}$ $(\mathrm{mm})$ is drainage below the root zone. A 24-h time step is used with daily precipitation and irrigation (if applied for an irrigated crop) as inputs to the model. Runoff is estimated from the total precipitation, relative fraction of soil water present, and soil water retention factor (McCuen 1982). Campbell's [1985, p. 92, Eq. (8.37)] equation is used in this model to calculate drainage.

The model calculates actual evaporation and transpiration separately and the summation of the two is ET. A modified Penman (1948) combination method of potential ET estimation is used to derive actual $E$ and $T$ where a wind function developed by Kincaid and Heermann (1974) is included. Actual evaporation is a function of potential ET and the number of days (ND) since the last precipitation occurred. The relationship between actual evaporation and potential ET can be expressed as follows:

$$
E=\mathrm{ET}_{p}(1 / \mathrm{ND})^{1 / 2}
$$

where $\mathrm{ET}_{p}$ is potential evapotranspiration based on the modified Penman method. Actual transpiration is a function of crop- and phenology-dependent crop coefficient $\left(K_{c}\right), \mathrm{ET}_{p}$, and a soil water reduction factor $(f)$. In the model, when the soil moisture content approaches wilting point, a soil water reduction factor restricts crop water use. This reduction factor is a function of available soil water and water-holding capacity of the soil, and changes in response to the ratio of available water to potential available water. Thus, actual transpiration is as follows:

$$
T=(f)\left(K_{c}\right)\left(\mathrm{ET}_{p}-E\right) .
$$

The rooting depth increases linearly with GDD in the model. At any one time the model treats the root zone as four equal layers and assumes $40 \%, 30 \%, 20 \%$, and $10 \%$ water extraction from each layer, respectively. These root layers are overlain on the five soil layers and the water is extracted from the soil layers that are currently occupied by roots. The soil moisture model simulates water in each layer, current water stress, runoff, drainage, phenology, actual and potential evapotranspiration, sensible heat flux, and net radiation.

It is noted above that the RH model was validated, and its performance evaluated, during the two growing seasons of 1986 and 1987 (Table 1) for five land uses at nine sites (representing varied soil conditions), for six layers up to 1.8-m depth in Nebraska (cf. RH; Camargo 1993; Camargo et al. 1994). Tables 1, 2, and 3 and Fig. 3 present detail of the model validation from RH. The sites are located in Nebraska (5), South Dakota (2), and Wyoming (2) (Table 1). Neutron probes were used to measure soil water at six depths: $15,45,75$, 105,135 , and $165 \mathrm{~cm}$. It was assumed that the data from each depth represent a soil layer of $30 \mathrm{~cm}$. Hence, these points are the midpoints for each of the $30-\mathrm{cm}$ soil layers. In addition, each of the nine locations represents varying root zone soil characteristics, for example, clay soil to sandy soil. If we combine location and land use, SM data were collected from 20 different land surface conditions (Table 1). Table 2 presents model evaluation statistics. Note that the index of agreement, also known as the " $d$ " index (Legates and McCabe 1999; Willmott 1981), can be expressed as follows: 
TABLE 2. Performance* of the soil water balance model. (Source: Robinson and Hubbard 1990.)

\begin{tabular}{|c|c|c|c|c|c|c|c|c|c|c|c|c|}
\hline Site & Year & Land use & $\mathrm{d}$ index & $r^{2}$ & $\begin{array}{l}\text { Mae } \\
(\mathrm{cm})\end{array}$ & $P(\mathrm{~cm})$ & $\sigma_{p}\left(\mathrm{~cm}^{2}\right)$ & $O(\mathrm{~cm})$ & $\sigma_{o}\left(\mathrm{~cm}^{2}\right)$ & $E_{s}(\mathrm{~cm})$ & $E_{u}(\mathrm{~cm})$ & Rmse $(\mathrm{cm})$ \\
\hline \multirow[t]{2}{*}{ North Platte, NE } & 1986 & Corn & 0.99 & 0.98 & 1.2 & 35.4 & 10.2 & 34.6 & 10.3 & 0.8 & 1.3 & 1.5 \\
\hline & & Wheat & 0.78 & 0.94 & 4.4 & 32.1 & 3.8 & 27.7 & 5.9 & 4.8 & 0.9 & 4.9 \\
\hline \multirow[t]{4}{*}{ North Platte, NE } & 1987 & Corn & 0.98 & 0.98 & 1.7 & 31.0 & 8.8 & 32.7 & 9.5 & 1.8 & 1.3 & 2.2 \\
\hline & & Wheat & 0.79 & 0.91 & 1.6 & 30.6 & 1.8 & 29.0 & 2.0 & 1.6 & 0.5 & 1.7 \\
\hline & & Sorghum & 1.00 & 0.99 & 1.1 & 39.1 & 9.7 & 38.9 & 10.8 & 1.1 & 0.8 & 1.4 \\
\hline & & Soybean & 0.96 & 0.99 & 3.1 & 36.7 & 7.8 & 33.6 & 9.0 & 3.4 & 0.7 & 3.4 \\
\hline \multirow[t]{4}{*}{ Clay Center, NE } & 1987 & Corn & 0.91 & 0.91 & 4.1 & 54.4 & 8.4 & 58.5 & 8.2 & 4.1 & 2.3 & 4.7 \\
\hline & & Wheat & 0.78 & 0.40 & 3.8 & 61.2 & 4.6 & 59.5 & 5.6 & 3.1 & 3.4 & 4.6 \\
\hline & & Sorghum & 0.98 & 0.98 & 1.7 & 61.0 & 8.3 & 59.6 & 9.5 & 1.8 & 1.0 & 2.0 \\
\hline & & Soybean & 0.96 & 0.96 & 2.0 & 62.5 & 6.7 & 64.5 & 7.0 & 2.1 & 1.3 & 2.4 \\
\hline \multirow[t]{3}{*}{ Concord, NE } & 1987 & Corn & 0.92 & 0.74 & 2.0 & 29.5 & 5.4 & 29.8 & 4.6 & 0.3 & 2.7 & 2.7 \\
\hline & & Sorghum & 0.75 & 0.67 & 4.6 & 28.8 & 6.5 & 24.2 & 5.4 & 4.6 & 3.5 & 5.8 \\
\hline & & Soybean & 0.70 & 0.78 & 7.9 & 40.6 & 6.7 & 32.7 & 7.5 & 8.0 & 3.0 & 8.6 \\
\hline \multirow[t]{2}{*}{ Mead, NE } & 1986 & Wheat & 0.79 & 0.98 & 2.9 & 45.4 & 3.1 & 42.5 & 6.2 & 4.0 & 0.4 & 4.0 \\
\hline & & Soybean & 0.79 & 0.71 & 2.7 & 58.0 & 3.6 & 55.3 & 4.3 & 3.0 & 1.7 & 3.4 \\
\hline Brookings, SD & 1987 & Corn & 0.95 & 0.93 & 1.1 & 24.4 & 3.3 & 25.1 & 4.3 & 1.2 & 0.7 & 1.4 \\
\hline Chamberlin, SD & 1987 & Corn & 0.96 & 0.95 & 1.0 & 29.1 & 3.5 & 30.1 & 4.0 & 1.2 & 0.7 & 1.4 \\
\hline Wheatland, WY & 1986 & Wheat & 0.84 & 0.68 & 1.0 & 22.6 & 1.5 & 23.4 & 1.7 & 1.0 & 0.8 & 1.3 \\
\hline Sidney, NE & 1987 & Wheat & 0.86 & 0.99 & 3.3 & 28.4 & 5.4 & 31.7 & 4.1 & 3.5 & 0.6 & 3.6 \\
\hline Chugwater, WY & 1987 & Grass & 0.86 & 0.77 & 1.2 & 26.5 & 1.5 & 26.1 & 2.6 & 1.3 & 0.7 & 1.5 \\
\hline
\end{tabular}

$*$ Mae $=$ mean absolute error, $P=$ predicted soil moisture, $O=$ observed soil moisture, $\sigma_{p}=$ variance of predicted soil moisture, $\sigma_{o}=$ variance of observed soil moisture, Rmse $=$ Root-mean-square error, $E_{s}=$ systematic component of rmse, $E_{u}=$ unsystematic component of rmse.

$$
d=1.0-\left[\frac{\sum_{i=1}^{N}\left(O_{i}-P_{i}\right)^{2}}{\sum_{i=1}^{N}\left(\left|P_{i}-\bar{O}\right|+\left|O_{i}-\bar{O}\right|\right)^{2}}\right],
$$

where $O$ and $P$ are observed and predicted values, respectively. The $d$ index takes into account differences in the observed and model-simulated means and variances and, thus, penalizes the model for consistent overor underestimation, even though the correlations may be high (Legates and McCabe 1999). This index varies from 0.0 to 1.0 , with higher values indicating better agreement between modeled and measured values. It is found that for most of the land uses the $d$ index is greater than 0.90 (Table 2). The spread of the $d$ index is between 0.70 to 1.0 (Table 2). The $r^{2}$ estimates also reported greater than 0.90 values for most (13 out of 20 cases) of the land uses (Table 2). The highest and the lowest $r^{2}$ estimates are 0.99 and 0.4 (0.67 is the second lowest), respectively. The observed and predicted SM values range between $23.4-64.5$ and $22.6-62.5 \mathrm{~cm}$, respectively (Table 2). Variances (standard deviation squared) for observed and predicted SM values range between 1.7-10.8 and 1.5-10.2 cm, respectively. High $d$ index values, high $r^{2}$ estimates, and a high degree of agreement in distribution of observed and predicted SM values and their variances clearly indicate that the model performance is satisfactory for various land uses with varying soil physical properties. Figure 3 shows the distribution of measured and observed SM and precipitation for five land uses at five locations. Small dots indicate measured SM and the thin line shows modeled SM. Again, it is apparent that the model is estimating SM satisfactorily. Precipitation events and the response of measured and modeled SM are also in close agreement. This suggests that phase and amplitude of modeled and measured SM are also in agreement.

Performance of the RH model was also evaluated for its estimation of SM at various depths in the root zone. Table 3 presents an example of model evaluation results at various depths in the root zone of corn at North Platte, Nebraska. It is found that the index of agreement $(d)$ and $r^{2}$ estimates for observed and modeled SM for six layers ranged between $0.88-0.98$ and $0.92-0.98$, re-

TABLE 3. Model performance by soil layer under corn land use: statistics for North Platte, NE. (Source: Robinson and Hubbard 1990.)

\begin{tabular}{|c|c|c|c|c|c|c|c|c|c|c|}
\hline $\begin{array}{l}\text { Soil layer } \\
\quad(\mathrm{mm})\end{array}$ & $\mathrm{d}$ index & $r^{2}$ & $\operatorname{Mae}(\mathrm{cm})$ & $P(\mathrm{~cm})$ & $\sigma_{p}\left(\mathrm{~cm}^{2}\right)$ & $O(\mathrm{~cm})$ & $\sigma_{o}\left(\mathrm{~cm}^{2}\right)$ & $E_{s}(\mathrm{~cm})$ & $E_{u}(\mathrm{~cm})$ & Rmse $(\mathrm{cm})$ \\
\hline $0-300$ & 0.97 & 0.94 & 0.5 & 5.6 & 1.8 & 6.0 & 1.8 & 0.4 & 0.4 & 0.6 \\
\hline $300-600$ & 0.95 & 0.97 & 0.7 & 5.6 & 2.1 & 6.2 & 1.7 & 0.7 & 0.4 & 0.8 \\
\hline $600-900$ & 0.99 & 0.98 & 0.4 & 5.6 & 2.1 & 5.6 & 1.7 & 0.3 & 0.3 & 0.4 \\
\hline $900-1200$ & 0.98 & 0.96 & 0.4 & 6.1 & 1.8 & 5.7 & 2.0 & 0.4 & 0.4 & 0.6 \\
\hline $1200-1500$ & 0.92 & 0.92 & 0.9 & 6.2 & 1.5 & 5.5 & 1.9 & 0.8 & 0.4 & 0.9 \\
\hline $1500-1800$ & 0.88 & 0.95 & 0.8 & 6.2 & 1.1 & 5.6 & 1.7 & 0.9 & 0.3 & 0.9 \\
\hline
\end{tabular}


Estimated and Observed Soil Water in Root Zone $(1070 \mathrm{~mm})$

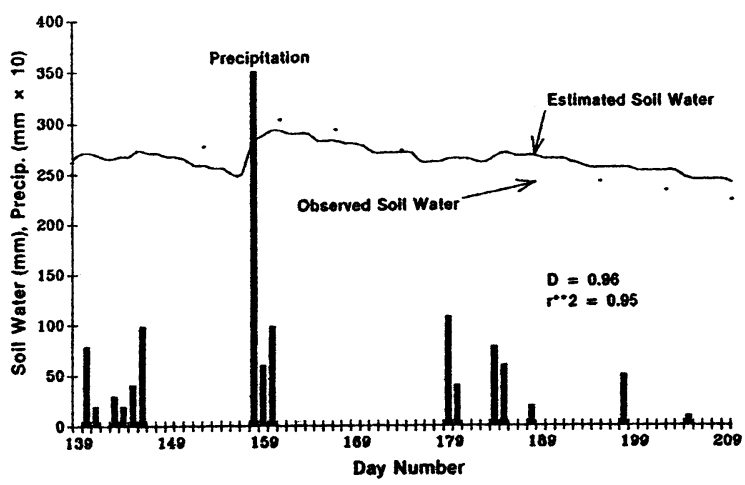

Estimated and Obeerved Sol Weter in Root Zone (1520 mm)

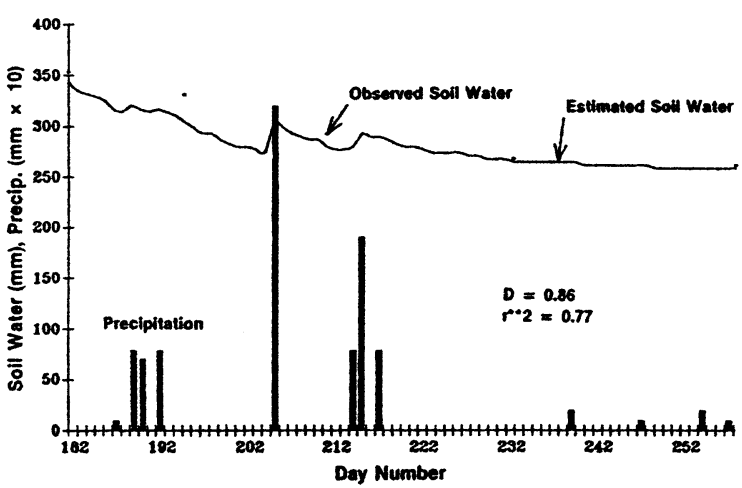
Estimated and Observed Soil Water in Root Zone $(1830 \mathrm{~mm})$

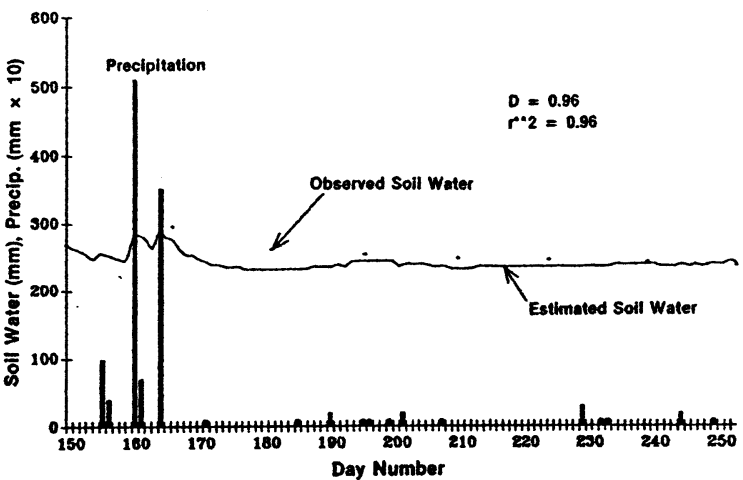

Rotimated and Observed Soil Fater in Root Zone $(1830 \mathrm{~mm})$
Under Sorghum at North Platte, NE Jun $2-$ Sep 8 1967

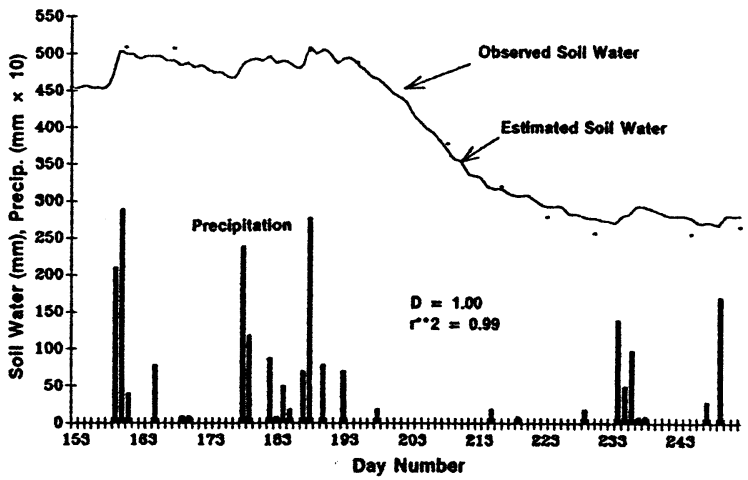

Estimated and Observed Soil Water in Root Zone (1520 mm)
Under Soybeans at Clay Center, NE Jun $30-$ Sep 301987

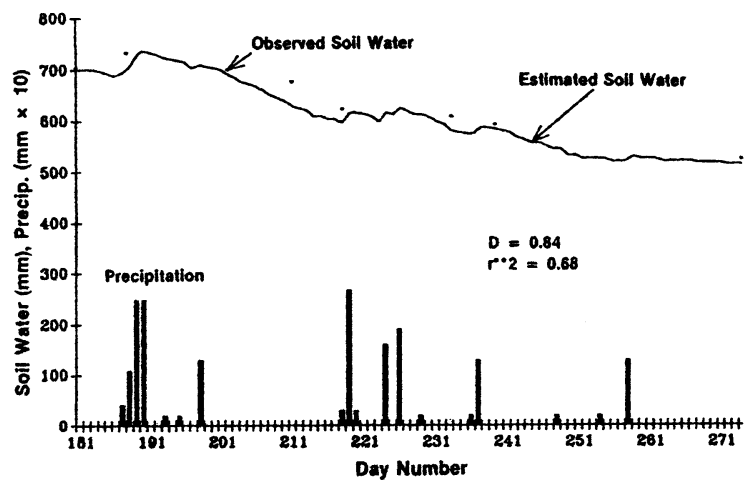

FIG. 3. Observed (dots) and modeled (line) root zone total SM for five land uses. (Source: Robinson and Hubbard 1990.) 
spectively (Table 3). Observed and predicted SM for these six layers of the root zone ranged between 5.56.2 and 5.6-6.2 cm, respectively (Table 3). Variances of the observed and predicted SM for these layers ranged between 1.7-2.0 and 1.1-2.1 cm, respectively. In summary, based on these evaluation results, it can be said that the RH model is satisfactorily estimating SM for various soil layers of the root zone.

A further assessment of the RH model performance was conducted by Camargo (1993) and Camargo et al. (1994). The model was validated for sorghum land use at Mead, Nebraska, in 1990 and 1991 where eight irrigation treatments were applied in a split plot design. The treatments were formulated based on plant phenological development where irrigation was applied and withheld in all possible combinations for three growth stages. Irrigation water was applied whenever plant available SM depleted to $50 \%$ of field capacity in the 0-90-cm layer. These experiments were conducted for the 1990 and 1991 growing season, and SM data were collected. Figure 4 shows results from model-estimated and observed SM. It is apparent from Fig. 4 that the RH model is estimating SM satisfactorily. The $d$ index and $r^{2}$ values for model estimates compared to the observed SM range from between $0.78-0.96$ and $0.64-$ 0.93 , respectively. Note that most of the $d$ index and $r^{2}$ values for model evaluation are above 0.90 and 0.80 , respectively. For the total of 16 treatment designs $(8+$ 8 treatment designs over $2 \mathrm{yr}$ ), 9 times the $d$ index exceeded 0.90 , and 14 times it exceeded 0.80 . On the other hand, for the same number of treatments over 2 $\mathrm{yr}, r^{2}$ reached over 0.80 for 12 occasions. The performance of the model, in regard to estimates of SM in the five soil layers (as assigned by Robinson and Hubbard 1990), was positive for 1990 and 1991. The $d$ index and $r^{2}$ estimate, reaching 0.95 and 0.96 , indicate satisfactory model performance. Recent applications show that the model is simulating soil water satisfactorily (Mahmood and Hubbard 2002a; Mahmood et al. 2001).

Based on the detailed quantitative comparison of model-estimated and measured SM, we suspect that the RH model performance is superior to Crawford et al.'s (2000) model, and also to many LSSs used in GSWP, AMIP, and PILPS. The other models, including LSSs, have not been evaluated in a comprehensive manner with multiple land uses, locations, and soils under significantly different hydroclimatic forcings. Validation is also completed for six depths from the surface to root zone. Four SM data-collection campaigns were undertaken to evaluate the RH model.

Crawford et al. (2000) conducted their validation by using only 1 month of data and for one land use. They (Crawford et al. 2000) have noted that $r^{2}$ between observed and simulated SM for 25-, 60-, and 75-cm depths ranged between 0.27 and 0.40 . For comparable depth ranges, $\mathrm{RH}$ recorded $r^{2}$ between 0.94 and 0.98 . Camargo et al. (1994) also found similar results and noted that $r^{2}$ values ranged between 0.73 and 0.96 . Thus, perfor-
TREATMENT H - 1990

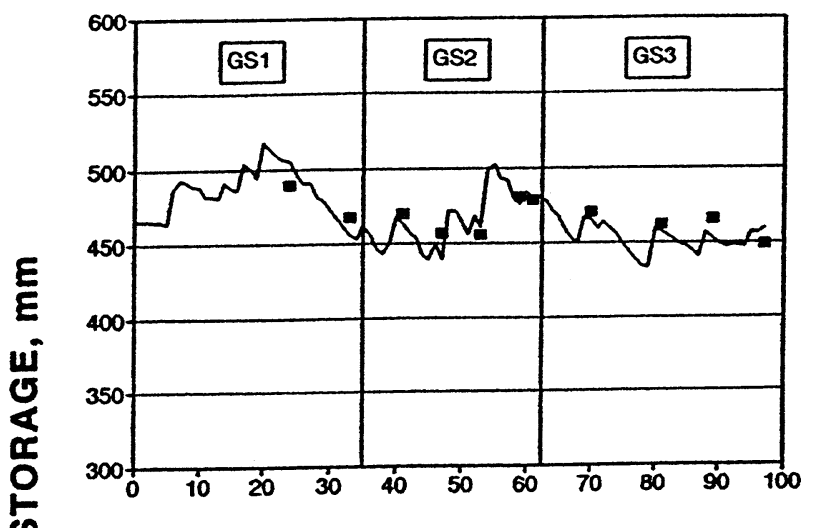

TREATMENT H - 1991

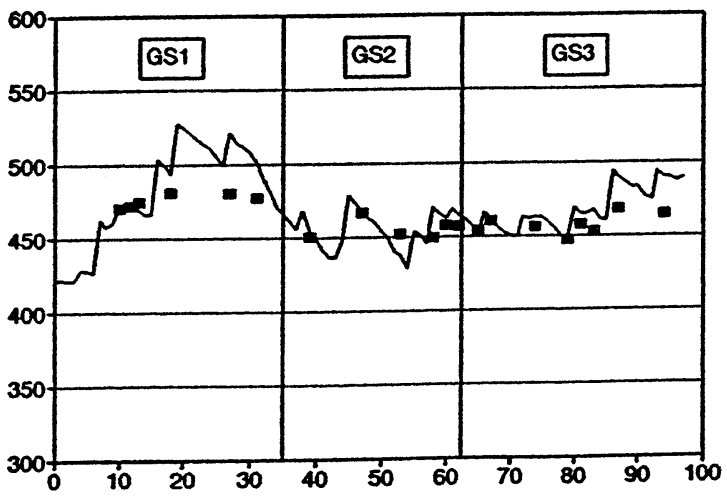

DAYS AFTER EMERGENCE

FIG. 4. Observed (small boxes) and modeled (line) root zone total SM for sorghum land use under treatment $\mathrm{H}$. This treatment is characterized by the application of irrigation water during all three growth stages. GS1: vegetative stage (planting to panicle initiation); GS2: infloresence stage [panicle initiation to anthesis (bloom)]; GS3: grainfilling stage (bloom to physiological maturity). (Source: Camargo et al. 1994.)

mance of the RH model is significantly superior. Crawford et al. (2000) noted that their model does not perform well in simulating SM at deeper layers. The evaluation of the RH model shows that its performance is superior and satisfactory for deeper layers (Table 3).

Our survey of literature shows that detailed quantitative assessment of the LSSs is notably deficient. Use of some of the well-established model evaluation methods was not employed and, thus, exact reliability of the LSS-estimated SM is unknown. Despite the availability of observed SM data for validation, most of the studies only show graphics on observed versus modeled SM and provide only qualitative assessment of the model performance. For example, Chen and Mitchell (1999) only plot observed and NCEP land surface model (LSM)-simulated SM and do not provide any quanti- 
TABLE 4. Distribution of clay, sand, and silt at three locations in NE.

\begin{tabular}{lccc}
\hline \hline Location & Clay $(\%)$ & Sand $(\%)$ & Silt $(\%)$ \\
\hline McCook & 15 & 20 & 65 \\
Clay Center & 30 & 10 & 60 \\
Mead & 65 & 5 & 30 \\
\hline
\end{tabular}

tative assessment on reliability of the model-estimated values. A discussion on seasonal changes in SM is not adequate. From visual examination we can state that large under- and overestimation of SM is prevalent for Chen and Mitchell's (1999) simulation. Similar qualitative assessment of LSS validation was provided for some of the major SM modeling efforts under the umbrella of GSWP, AMIP, and PILPS (e.g., Matsuyama et al. 1999; Zhang et al. 1999). In the absence of quantitative evaluation, graphic presentation of observed and modeled data indicates a significant amount of disagreement. Matsuyama et al. (1999), in the application of Japan Meteorological Agency's Simple Biosphere Model $(\mathrm{SiB})$ found a consistent underestimation of estimated SM, compared to observed SM. After evaluating GSWP SM simulations, Entin et al. (1999) correctly noted that none of the models do a satisfactory job in estimating SM. Dirmeyer et al. (1999) agreed with this observation.

Schlosser et al. (2000) also qualitatively assessed performance of $21 \mathrm{LSSs}$ for Valdai, Russia. This evaluation was conducted for only one land use, namely, grass, as opposed to our quantitative evaluation for five land uses at nine locations. Chen et al. (1997) "evaluated" performance of the $23 \mathrm{LSS}$ schemes without comparing simulated values with measured values during the $\mathrm{Ca}$ bauw, Netherlands, experiment. Schlosser et al. (1997) evaluated the performance of the Simple SiB (SSiB) LSS for Valdai, Russia. The variance of model-estimated and observed SM data shows a large disagreement and departure from each other. Our model evaluation shows close agreement between estimated and observed SM (Tables 2 and 3). Previously, Robock et al. (1995) have shown bias associated with SSiB and the bucket model-estimated SM values. The bias was associated with incorrect specification of field capacity (Robock et al. 1997). Another LSS, namely, a two-layer VIC(-2L) (Liang et al. 1996) was evaluated, but the location and model evaluation statistics presented are minimal. This limited evaluation failed to convey the exact reliability of the model.

It can be concluded, for LSSs used in GSWP, PILPS, and AMIP, that 1) the quantitative assessment of the accuracy of modeled SM is absent or severely limited, 2) the qualitative assessment is prevalent, 3) the "validation" is largely conducted for one land use-grass, 4) the validation data used are for only one location, despite the availability of data from additional sites, and 5 ) the departures of model variance (only one study applied this statistic for evaluation) and estimates from observed data were large. As noted above, for the $\mathrm{RH}$
TABLE 5. Selected hydrologic properties (in volumetric water content) $\mathrm{mm}^{3} \mathrm{~mm}^{-3}$ of soils at three sites in NE.

\begin{tabular}{ccccc}
\hline \hline Location & Depth $(\mathrm{cm})$ & $\begin{array}{c}\text { Saturation } \\
\text { point }\end{array}$ & $\begin{array}{c}\text { Field } \\
\text { capacity }\end{array}$ & $\begin{array}{c}\text { Wilting } \\
\text { point }\end{array}$ \\
\hline McCook & $0-2.5$ & 0.46 & 0.36 & 0.22 \\
& $2.5-30.5$ & 0.52 & 0.36 & 0.22 \\
& $30.5-61$ & 0.48 & 0.36 & 0.22 \\
& $61-91.5$ & 0.42 & 0.36 & 0.22 \\
Clay Center & $91.5-122$ & 0.46 & 0.36 & 0.22 \\
& $0-2.5$ & 0.46 & 0.32 & 0.12 \\
& $2.5-30.5$ & 0.52 & 0.32 & 0.16 \\
Mead & $30.5-61$ & 0.48 & 0.33 & 0.17 \\
& $61-91.5$ & 0.42 & 0.33 & 0.14 \\
& $91.5-122$ & 0.46 & 0.34 & 0.14 \\
& $0-2.5$ & 0.46 & 0.36 & 0.18 \\
& $2.5-30.5$ & 0.55 & 0.36 & 0.18 \\
& $30.5-61$ & 0.65 & 0.40 & 0.20 \\
& $61-91.5$ & 0.65 & 0.40 & 0.20 \\
& $91.5-122$ & 0.59 & 0.42 & 0.20 \\
\hline
\end{tabular}

model, we have completed a detailed quantitative assessment (Tables 2 and 3; Figs. 3 and 4). All of the model evaluation statistics applied suggest that the model performance is satisfactory under various land uses, root zone soil conditions, and hydroclimatic regimes (Tables 2 and 3). Based on the model evaluation statistics, we are able to indicate how well the model is performing and how reliable the model estimates are. Visual assessment is not sufficient, as shown by many LSS evaluation exercises. Therefore, based on the results from quantitative assessment and the accuracy of calculated SM values, we conclude that the RH model will provide satisfactory estimates of SM for the study area.

For this study, the RH model is applied for three predominant land uses and associated soils characteristics in Nebraska, namely, irrigated and rain-fed corn, and rain-fed grass. Three sites in Nebraska were selected to simulate the SM climate under varying land use and moisture regimes. The Mead, Clay Center, and McCook sites (Fig. 1) follow an east-west gradient from moist (Mead) to very dry (McCook) conditions. There were three applications per site (three types of land use and one soil type). The setting allows us to estimate and understand potential responses of SM in more than one moisture regime. Daily weather data for the RH model simulations were provided by the automated weather stations at these locations. Site-specific soil input data for the model application are available from a soils database maintained by the High Plains Regional Climate Center (HPRCC). These data include bulk density, soil texture, wilting point, field capacity, and saturation point for each soil layer (Tables 4 and 5).

In this paper total plant available root zone water $(\mathrm{SM})$ is presented as water depth, and individual layer $\mathrm{SM}$ is presented as volumetric water content $\left(\mathrm{mm}^{3}\right.$ $\left.\mathrm{mm}^{-3}\right)$. In the following discussions, we chose to emphasize temporal distribution of SM over $1 \mathrm{yr}$ by using daily estimates. An analysis of seasonal variations of $\mathrm{SM}$ is not discussed here. 

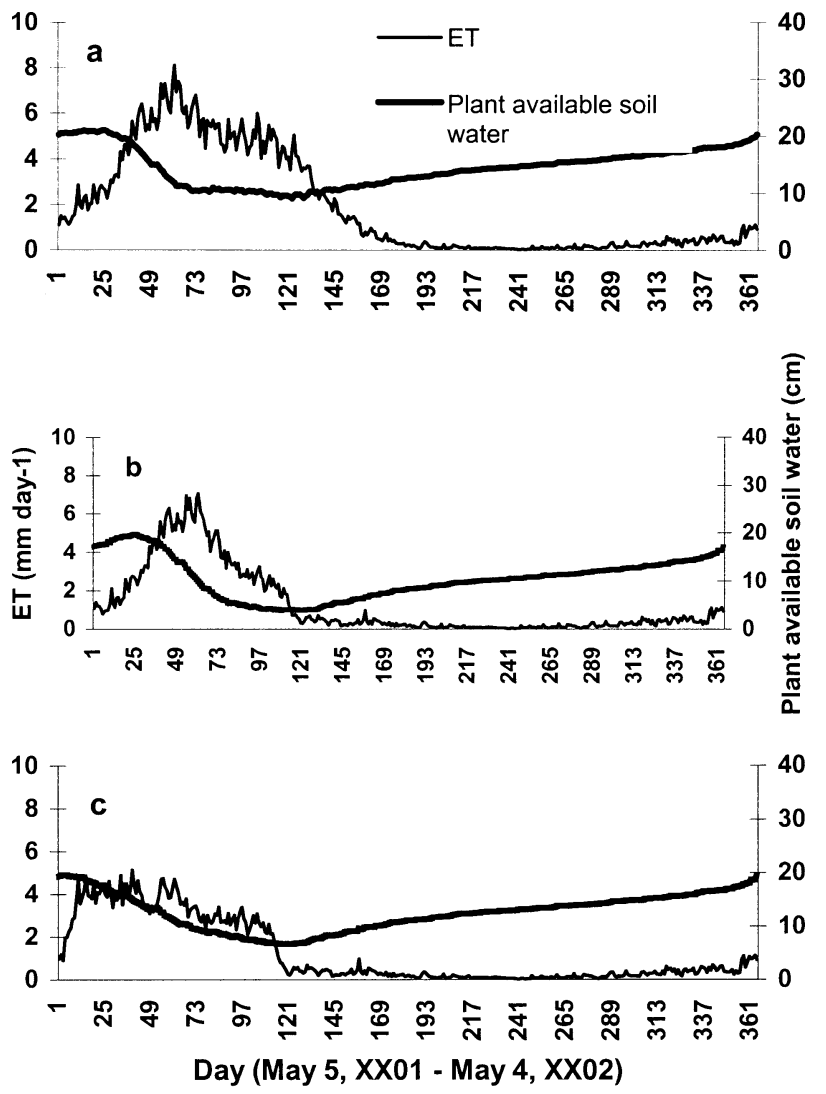

FIG. 5. Mean daily (1982-99) evapotranspiration and plant available soil moisture for McCook, NE: (a) irrigated corn, (b) rain-fed corn, and (c) grass. Day $1=5$ May.

\section{Applications of SM model and results \\ a. Plant available root zone SM and ET}

The RH model was run from 1982 to 1998 for the three land uses: irrigated corn, rain-fed corn, and rainfed grass. The beginning of growing season was set as 5 May, and the model completes each run on 4 May of the subsequent year. Soil water balance from each year was carried over to the following year. Three separate accumulated GDDs were included during the model simulations to reflect phenological development of grass, and rain-fed and irrigated corn. Accumulated degree days, with the progression of the growing season, mark the end of a phenological stage and the beginning of the next stage. Accumulated growing degree days are the summation of temperatures for the whole growing season through the date of interest, wherein a baseline/ critical/threshold temperature is subtracted from the daily mean temperature prior to summation. The baseline temperature indicates a lower limit on the thermal environment above which sustained development of plants is supported. The selection of growing degree days is important because phenological development notably influences the crop's growing season water consumption and its utilization. In due course, this affects soil water

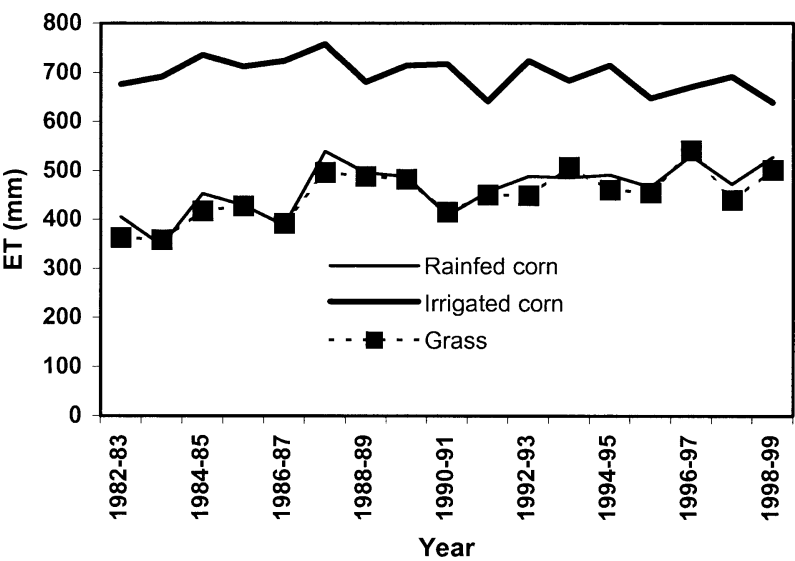

FIG. 6. Annual total evapotranspiration from three land uses at McCook, NE. (Source: Mahmood and Hubbard 2002a.)

status, evapotranspiration rates, and energy balance. To avoid stress, irrigation was applied when root zone soil water reached the midpoint between field capacity and wilting point.

The model allows interannual variations in thermal conditions to affect the length of plant growth and development and, thus, the length of time to reach maturity. In other words, like in the "real world," interannual variations, in the required length of time for plants to reach maturity, are simulated by the model. We have found that the model simulates plant maturity periods correctly.

Predictably, the application of the RH soil water model to the westernmost site (McCook, Nebraska) indicates, on average, that the amount of plant available soil water throughout the growing season is relatively higher for irrigated corn compared to rain-fed corn and grass (Figs. 5a-c). Likewise, the supply of water by irrigation to match plant requirements led to relatively higher available soil moisture. However, simulations suggest rapid depletion of SM due to vigorous consumption of water by rain-fed corn (Fig. 5b). On average, during a growing season, the lowest amount of plant available soil water is 9,4 , and $6 \mathrm{~cm}$ for irrigated and rain-fed corn, and grass, respectively (Figs. 5a-c). The model application shows relatively high daily rates of ET under irrigated corn results in significantly higher annual totals compared to rain-fed corn and grass (Fig. 6). According to the RH model, annual total ET values for irrigated and rain-fed corn, and grass, on the average, are 694, 462, and $449 \mathrm{~mm}$, respectively. In other words, average annual total ET under irrigated corn is $34 \%$ and $36 \%$ greater compared to rain-fed corn and grass, respectively.

At Clay Center, the temporal pattern in mean daily ET and plant available SM is similar to that at McCook (Figs. 7a-c). Results suggest that the mean daily plant available SM is the highest for irrigated corn and lowest for rain-fed corn (Figs. 7a and 7b). It is found that, in Clay Center, the lowest mean daily plant available SM 

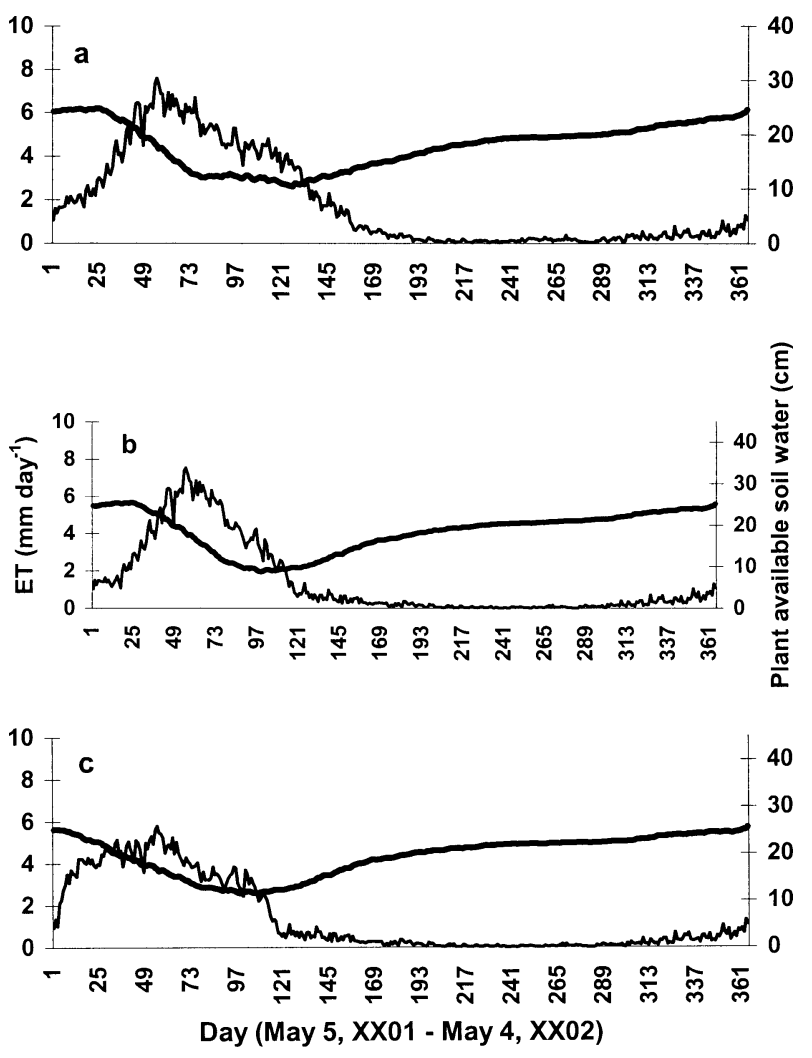

FIG. 7. Mean daily (1982-99) evapotranspiration and plant available soil moisture for Clay Center, NE: (a) irrigated corn, (b) rainfed corn, and (c) grass. Day $1=5$ May. See Fig. 5a for legends.

for irrigated and rain-fed corn and grass are approximately 11,9 , and $11 \mathrm{~cm}$, respectively. Our calculation shows that average annual total ET values for irrigated and rain-fed corn and grass are 683, 521, and $503 \mathrm{~mm}$, respectively (Fig. 8). Hence, at Clay Center, annual ET from irrigated corn is $27 \%$ and $24 \%$ higher compared to grass and rain-fed corn, respectively. At this location, atmospheric demand for higher rates of evapotranspiration from rain-fed corn and grass was fulfilled, due to relatively higher precipitation.

A similar pattern occurs at Mead (Figs. 9a-c). However, daily mean plant available moisture is higher for all three land uses at Mead compared to McCook and Clay Center. The lowest mean daily plant available SM for irrigated and rain-fed corn, and grass is 12, 14, and $17 \mathrm{~cm}$, respectively. The lowest mean daily plant available SM is reported by land use under irrigated, not rain-fed, corn. The primary reason is that the growing season for irrigated corn is longer, and natural plant available SM quantity is higher due to the moist, subhumid environment. Also, water-holding capacity of the soil is higher at this location. The latter allowed plants to use soil water for a longer period before requiring irrigation water. On the other hand, the shorter growing season for rain-fed corn prohibited these plants from using as much water as irrigated corn. The annual total

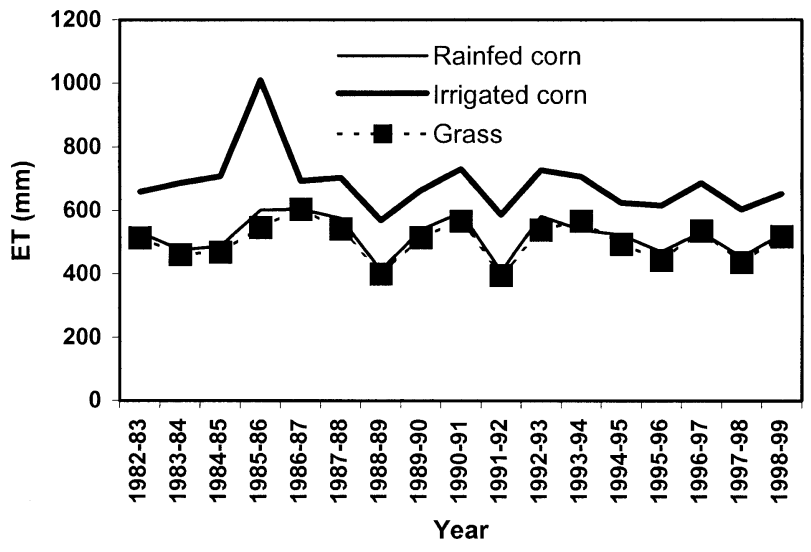

FIG. 8. Annual total evapotranspiration from three land uses at Clay Center, NE. (Source: Mahmood and Hubbard 2002a.)

ET from the irrigated corn is generally higher compared to rain-fed corn and grass and for any given year (Fig. 10). This study reports that the average annual total ET values for irrigated and rain-fed corn, and grass are 625, 544 , and $531 \mathrm{~mm}$, respectively. Thus, on the average, annual ET for irrigated corn is $16 \%$ and $13 \%$ higher compared to grass and rain-fed corn, respectively.
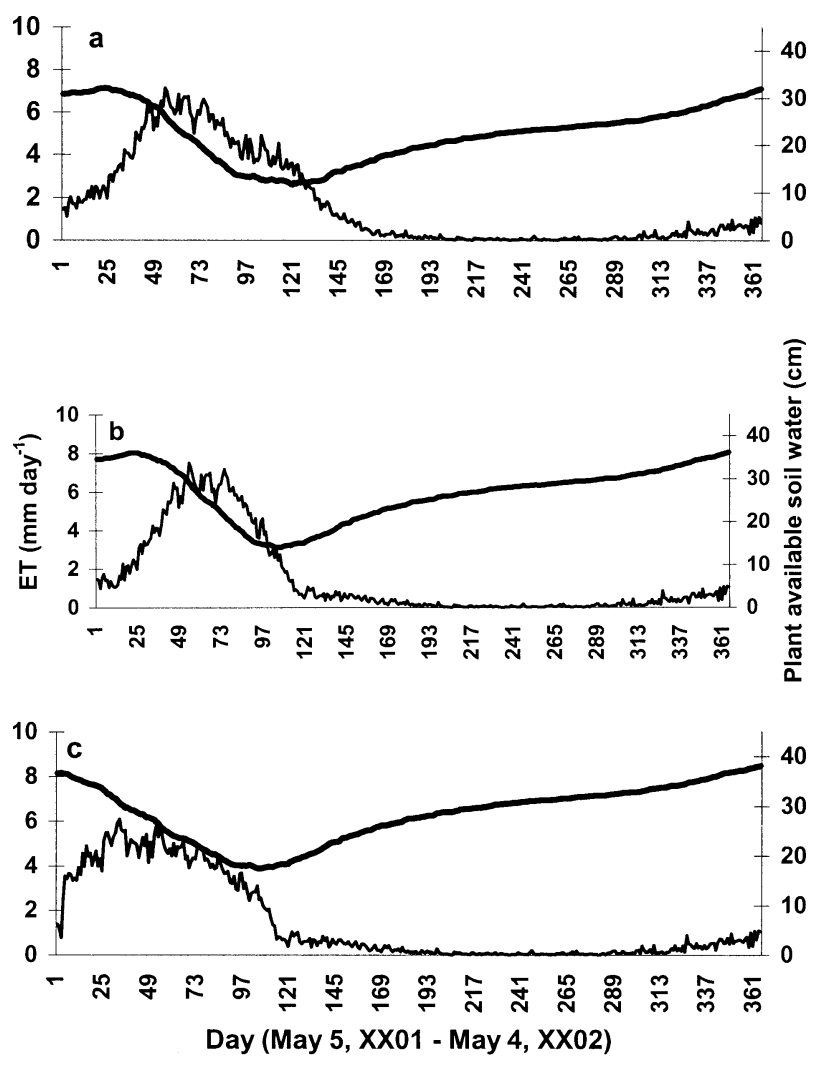

FIG. 9. Mean daily (1982-99) evapotranspiration and plant available soil moisture for Mead, NE: (a) irrigated corn, (b) rain-fed corn, and (c) grass. Day $1=5$ May. See Fig. 5a for legends. 


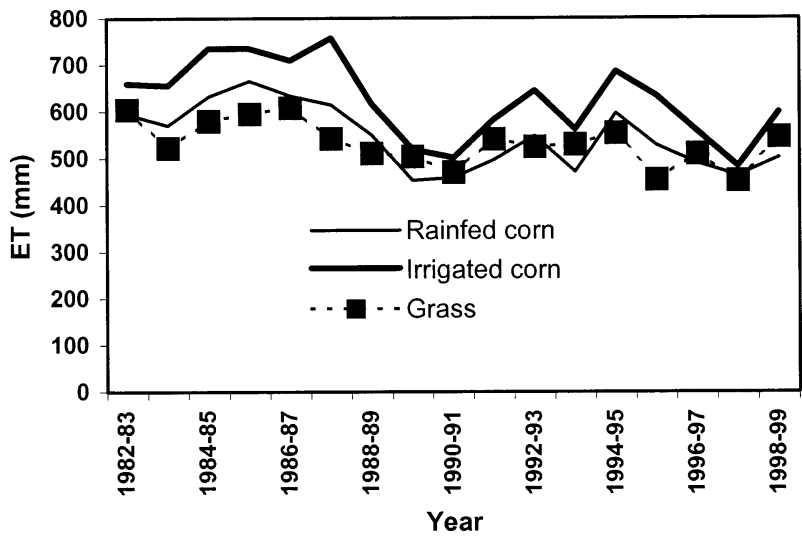

FIG. 10. Annual total evapotranspiration from three land uses at Mead, NE. (Source: Mahmood and Hubbard 2002a.)

\section{b. SM at various depths of the root zone}

The mean daily SM estimates for McCook show relatively more fluctuations of soil water content in the top soil layer (a $2.5-\mathrm{cm}$ layer at the surface) under irrigated corn (Fig. 11a). As expected, this layer responds quickly under a precipitation event or during a dry spell. As a result, both the lowest and highest volumetric water content for top soil is lower compared to the second layer $(2.5-30.5 \mathrm{~cm})$. The fluctuation in soil water content is higher during the plant growing period, prior to maturity. The second layer of the soil shows far less fluctuation. Soil water depletes steadily at the beginning of the plant growing season (Fig. 11b). It is found that soil water depletes most rapidly in the third layer (30.5$61 \mathrm{~cm})$, followed by the fourth $(61-91.5 \mathrm{~cm})$ and fifth $(91.5-122 \mathrm{~cm})$ layers (Figs. 11c-e).

Figures 12a-e show temporal soil water distribution for various soil layers under rain-fed corn. Soil water content at the top soil layer at McCook shows fluctuations that resemble conditions under irrigated corn (cf. Figs. 12a and 11a). It is also apparent that under rainfed farming, volumetric soil water contents remain below 0.25 for a much longer time period (113 days), compared to irrigated corn ( $<15$ days). Under grass, soil water at McCook depletes from the second layer more rapidly, compared to rain-fed corn (Fig. 12f). Plant growth and crop-specific phenology caused such differences. Also, soil water content at the second layer remains below 0.25 for a longer period of time (124 days) under grass land use, compared to rain-fed corn. Grass does not extract as much soil moisture as rainfed corn. As a result, under grass, soil water at the fourth and fifth layers never reaches the lows encountered under rain-fed corn (Fig. 12h).

Mean daily SM patterns at Clay Center resemble those at McCook. However, the notable difference is that soil water content for all three land use/land covers at Clay Center never reduces to the level of McCook (Figs. 13a-e; rain-fed corn is shown, e.g.). Obviously,
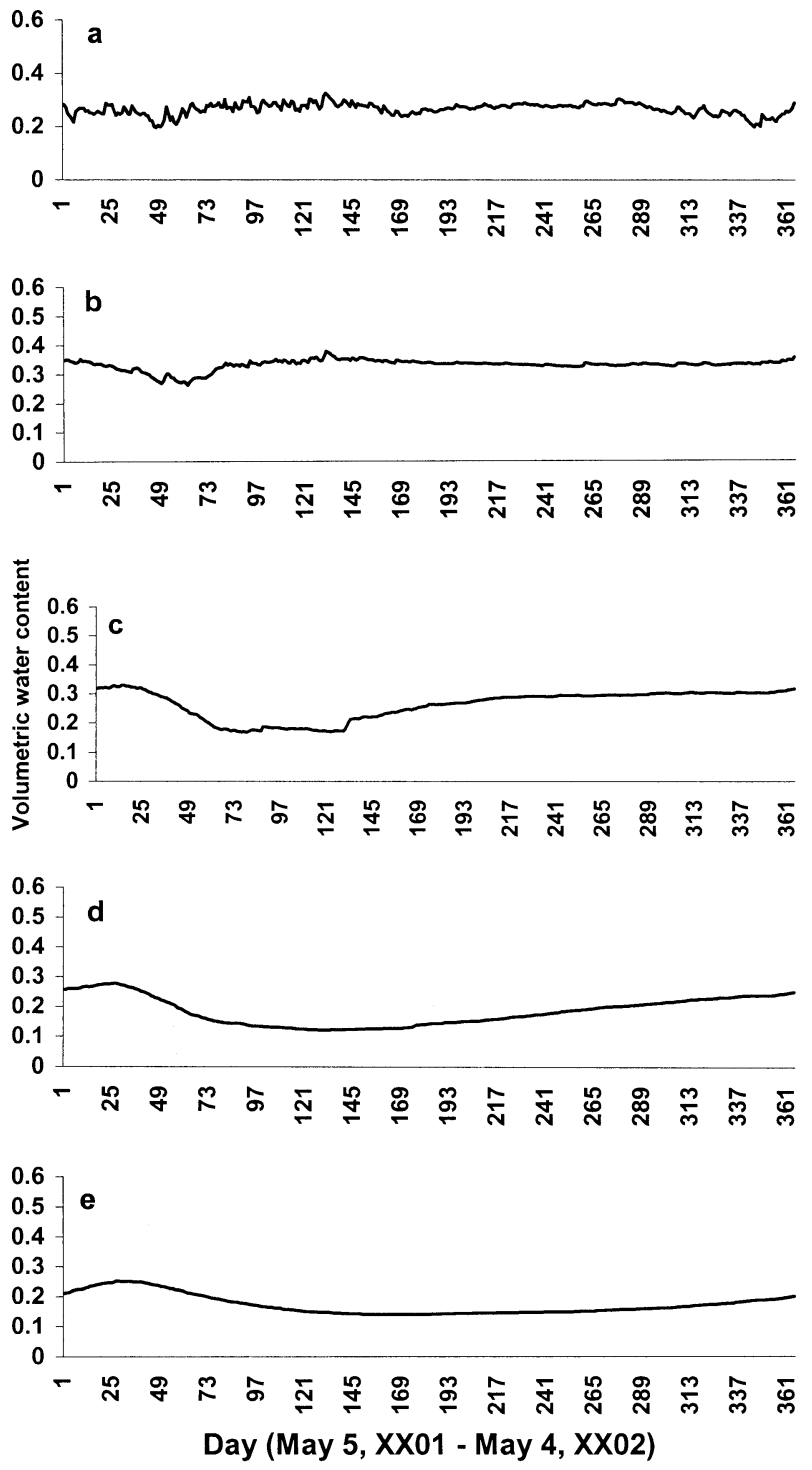

FIG. 11. Mean daily volumetric soil water content for irrigated corn at McCook, NE: (a) top, (b) second, (c) third, (d) fourth, and (e) fifth layers. Day $1=5$ May.

a relatively moist hydroclimatic condition is the cause of such difference.

The amplitude of the soil water content under irrigated corn in the top layer is twice as much at Mead compared to that at McCook and Clay Center (Figs. 11a and 14a; Clay Center is not shown). Soil water contents in the second, third, and fourth layers show similar characteristics at Mead (Figs. 11b-d and 14b-d). Under rainfed corn, Mead, again, shows a relatively larger amplitude of SM content in the top second, third, and fourth layers compared to that at Clay Center and McCook (not shown). The amplitude of SM in the fifth layer is smaller at Mead than at Clay Center (not shown). Due to moist hydroclimatic conditions, rain-fed corn mines SM mostly from the top four layers. Interestingly, the 

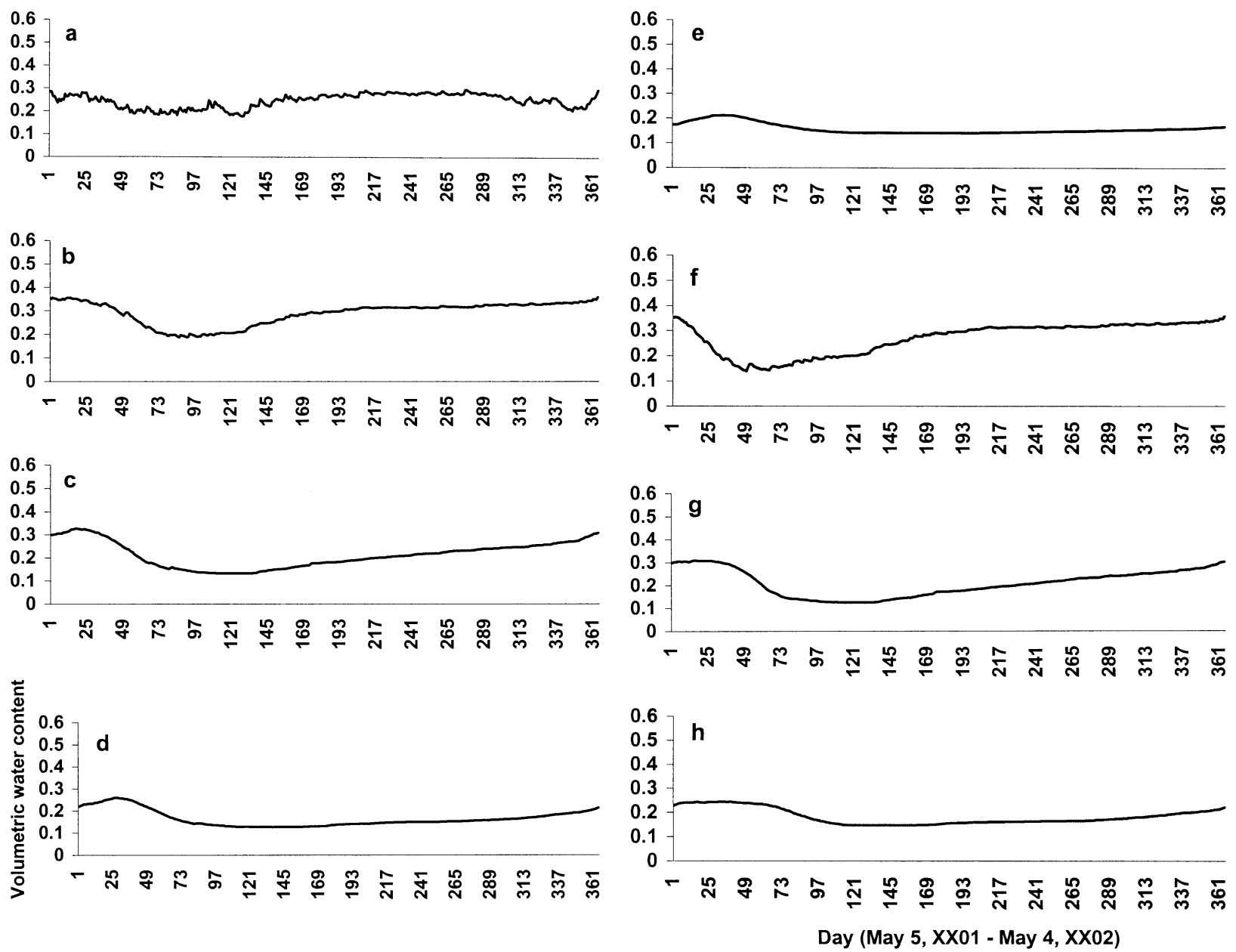

FIG. 12. Mean daily volumetric soil water content for rain-fed corn at McCook, NE: (a) top, (b) second, (c) third, (d) fourth, and (e) fifth layers; and for grass: (f) second, (g) third, and (h) fourth layer. Day $1=5$ May.

difference in SM content among the top three layers under rain-fed corn at Mead is much less, compared to Clay Center and McCook. At the beginning of the growing season, similar to McCook and Clay Center, grass starts extracting SM from the top layer more vigorously, compared to rain-fed and irrigated corn. Also, it extracts most of the required water from the top three layers. As a result, SM content is lower at these layers, compared to rain-fed and irrigated corn.

\section{c. Statistical aspects of SM at various depths in the root zone}

Under irrigated and rain-fed corn and grass land use, mean daily volumetric water content in almost all layers is higher at Mead compared to the other two locations (Tables 6-8). As noted above, hydroclimatologically, Mead is a relatively moist site compared to McCook and Clay Center. At all sites and under these three land uses the second layer of the soil profile is relatively moist. The top layer of the soil loses moisture more quickly, largely due to evaporation. Relatively less moisture reaches the lower layers of the soil profiles after drainage to the second and third layers. Under irrigated corn land use, the coefficient of variation (CV) estimates suggest that SM at the second layer of the soil profile is the least variable, while the fourth and fifth layers are the most variable. Relatively higher interannual variations in SM content at these deeper layers resulted in higher variability estimates. Similar patterns are seen for rain-fed corn land use at Mead (Figs. 15a,b). For grass, SM variability at the fourth and fifth layers is not as high as for rain-fed and irrigated corn, and is lowest compared to other layers (Tables 6-8). Grass does not extract as much moisture compared to rain-fed and irrigated corn, resulting in lower variability. Relatively higher mean values of SM content in the fourth and fifth layers under grass also reflect this condition. As noted above, compared to rain-fed corn, slightly lower SM in the top three layers under grass indicates relatively higher use of water from these layers by grass.

A relative moisture availability index (RMAI) can be used to further investigate SM variations in the (total) root zone under these three land uses. RMAI is the ratio 

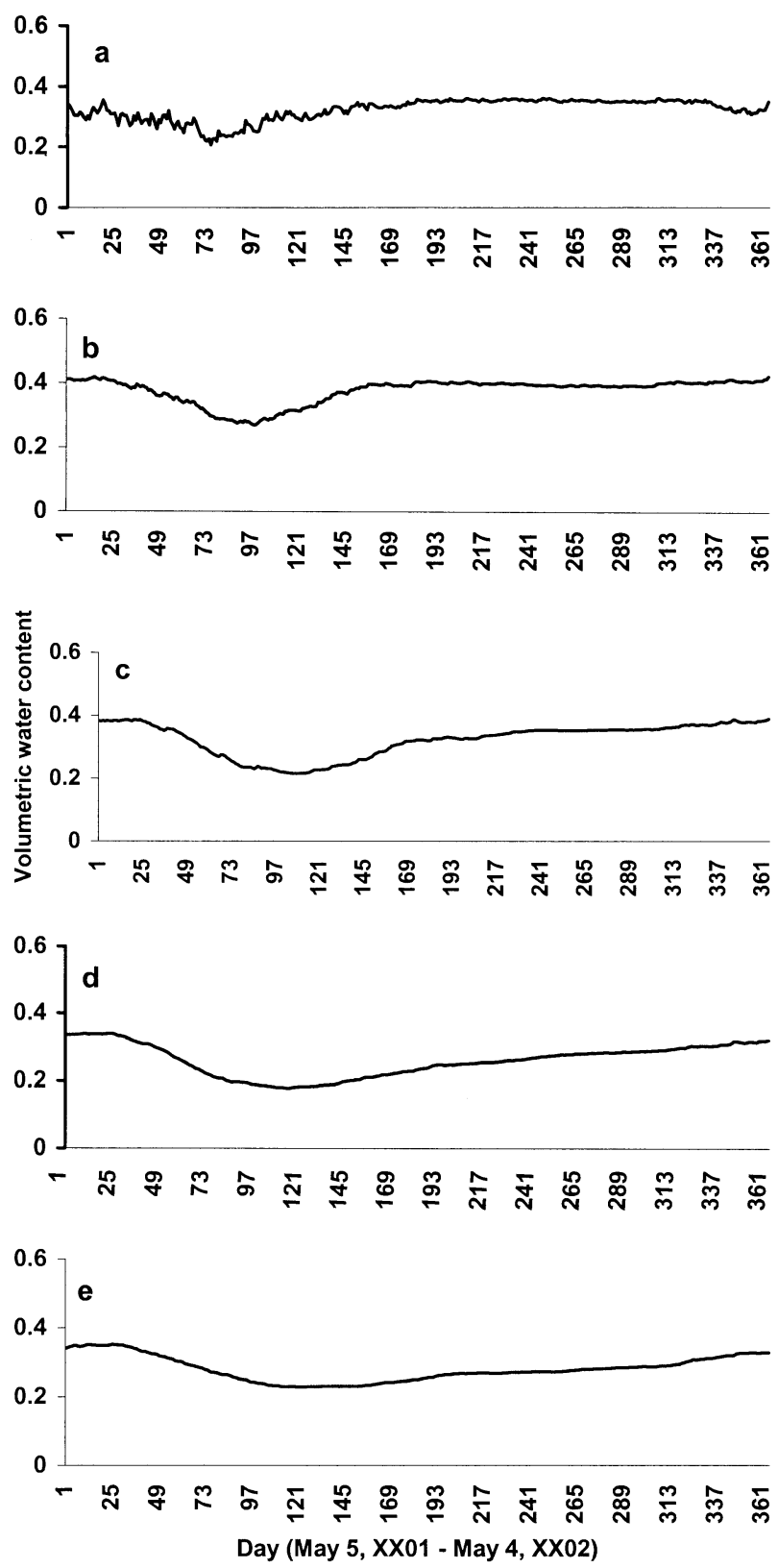

FIG. 13. Mean daily volumetric soil water content for rain-fed corn at Clay Center, NE: (a) top, (b) second, (c) third, (d) fourth, and (e) fifth layers. Day $1=5$ May.

of plant available soil water to the difference between field capacity and the wilting point. Plant available soil water is the difference between total soil water in the root zone and wilting point. Thus, this index provides a standardized view of soil water under three crops in three moisture regimes. Physically, the lower the index value, the drier the soil and the lower the plant available SM. RMAI values larger than 1 indicate that the soil water is higher than the field capacity, which happens as soils approach saturation. Mean daily annual RMAI is the lowest and highest at McCook and Mead, re-
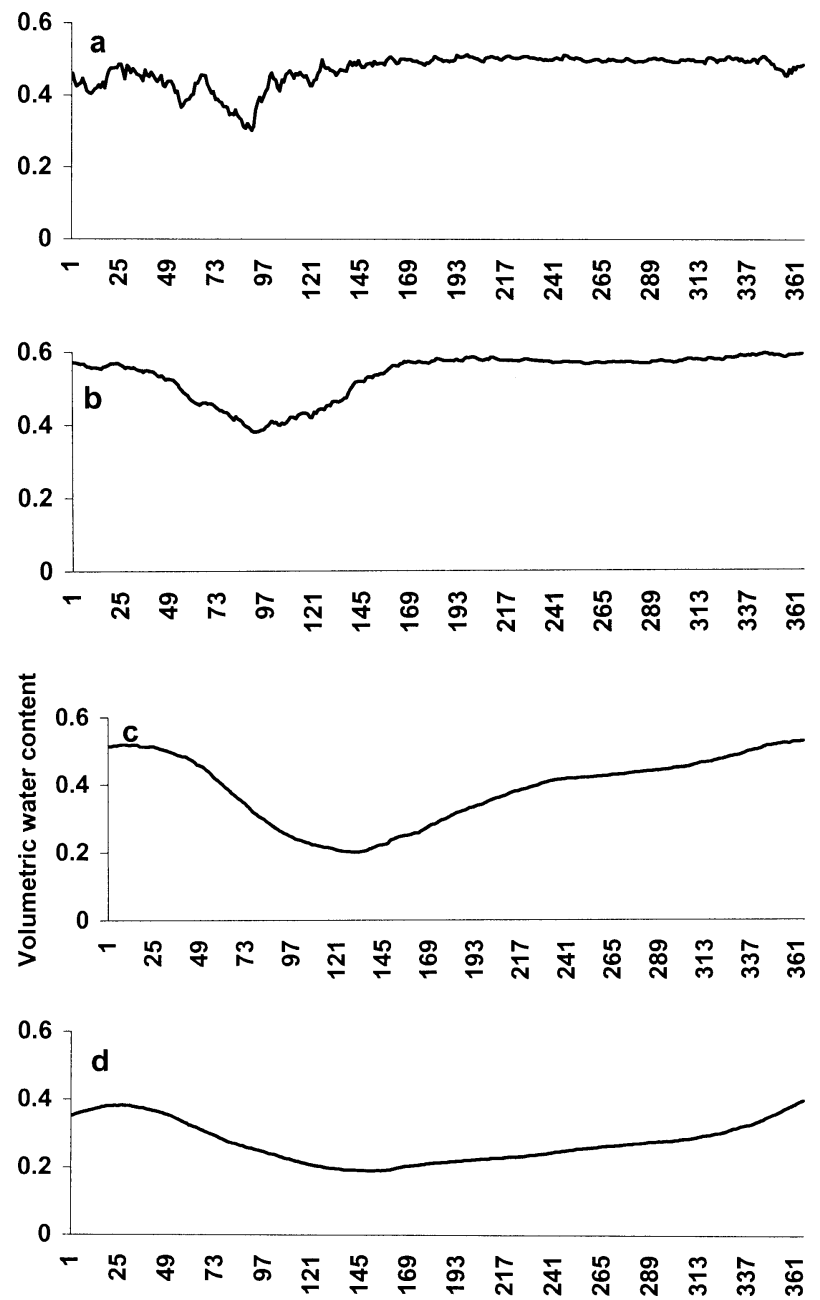

FIG. 14. Mean daily volumetric soil water content for irrigated corn at Mead, NE: (a) top, (b) second, (c) third, and (d) fourth layers. Day $1=5$ May

spectively, under irrigated corn, and rain-fed corn and grass. Mean daily annual RMAI fluctuates more at Mead compared to the other sites of this study (Figs. 16a-c). This primarily indicates higher variability in moisture availability. RMAI values also reflect excessively wet and dry conditions. For example, high RMAI values at Mead and Clay Center in 1993-94 coincides with extremely wet conditions and flooding in the Mississippi River basin. On the other hand, the low RMAI value for 1983-84 at McCook is associated with severe drought conditions during this year and for the previous year, 1982-83.

\section{d. Total root zone soil moisture variability at various temporal scales}

Quantitative assessment of variations in root zone soil moisture at various temporal scales including daily, monthly, and annual, can play an important role in designing mesoscale and climate models. A clear under- 
TABLE 6. Descriptive statistics for soil moisture (volumetric water content) under irrigated corn at three sites in NE for the period 1982-98. Depths are shown for each layer.

\begin{tabular}{|c|c|c|c|c|c|c|}
\hline Station & Parameters & $\begin{array}{c}\text { Layer } 1 \\
0-2.5 \\
(\mathrm{~cm})\end{array}$ & $\begin{array}{c}\text { Layer } 2 \\
2.5-30.5 \\
(\mathrm{~cm})\end{array}$ & $\begin{array}{c}\text { Layer } 3 \\
30.5-61 \\
(\mathrm{~cm})\end{array}$ & $\begin{array}{c}\text { Layer } 4 \\
61-91.5 \\
(\mathrm{~cm})\end{array}$ & $\begin{array}{c}\text { Layer } 5 \\
91.5-122 \\
(\mathrm{~cm})\end{array}$ \\
\hline \multirow{3}{*}{ McCook } & Mean & 0.26 & 0.33 & 0.26 & 0.18 & 0.17 \\
\hline & Std dev & 0.06 & 0.03 & 0.06 & 0.06 & 0.05 \\
\hline & $\mathrm{CV}$ & 23 & 9 & 23 & 33 & 29 \\
\hline \multirow[t]{3}{*}{ Clay Center } & Mean & 0.31 & 0.37 & 0.32 & 0.24 & 0.25 \\
\hline & Std dev & 0.05 & 0.03 & 0.06 & 0.07 & 0.06 \\
\hline & $\mathrm{CV}$ & 16 & 8 & 18 & 29 & 24 \\
\hline \multirow[t]{3}{*}{ Mead } & Mean & 0.46 & 0.53 & 0.38 & 0.27 & 0.16 \\
\hline & Std dev & 0.08 & 0.08 & 0.14 & 0.12 & 0.04 \\
\hline & $\mathrm{CV}$ & 17 & 15 & 36 & 44 & 25 \\
\hline
\end{tabular}

standing of how soil moisture varies at different temporal scales and under different land uses provides important clues to how land surface moistness influences boundary layer atmospheric modulation. This would improve our forecasting and diagnostic skills for weather and climate. The following discussion presents a quantitative assessment of how SM varies at different temporal scales under heterogeneous land use, soils, and hydroclimatic conditions.

We calculated CV (\%) of total root zone SM for each day for all three land uses at each location. At McCook, irrigated corn shows the least day-to-day variability and remains nearly stable over the course of a year (Fig. 17a). The daily SM variability hovers around $20 \%$ most of the time. The primary reason for such low day-today variability for irrigated land use is related to the very dry conditions and resultant frequent application of irrigation to remove SM deficits and plant water stress. Under rain-fed corn land use, SM variability increases rapidly to $>100 \%$ at $\mathrm{McCook}$ as the growing season progresses (toward maximum plant growth), and it diminishes as the plant completes its growth cycle (Fig. 17b). The rate of increase in variability is also very high under rain-fed corn land use (Fig. 17b). The high variability is a function of dry hydroclimatic conditions and the plant's sole reliability on rainfall for moisture. In other words, the rapidly increasing demand for moisture with the growth of plant, low rainfall ac- companied by high day-to-day variability, and the absence of irrigation resulted in such high day-to-day SM variability. Under grass land use, the maximum variability reaches nearly $50 \%$ as the season progresses. Note that the rate of increase of variability is much less compared to rain-fed corn (Figs. 17b and 17c). For rainfed corn daily variability increased from nearly $20 \%$ to $60 \%$ (three fold increase) between day 49 and day 73 , while for grass this jump is from $20 \%$ to $30 \%$. The much greater demand of moisture by corn results in this greater variability.

At Mead, the total root zone SM variability for irrigated and rain-fed corn is nearly identical (Figs. 18a and 18b). Mead is a moist location compared to McCook and, thus, the demand for irrigation is less. In addition, the Mead soil has a higher water-holding capacity (predominantly clay soil, Table 4) compared to the McCook soil, and naturally occurring rainfall is the predominant supplier of moisture for both irrigated and rain-fed corn. The small differences in CV between these two land uses results primarily from different water consumption characteristics and plant phenologies. The root zone variability shown by grass is also primarily a result of water consumption characteristics and phenology (Fig. 18c). Clay Center generally follows the pattern of responses demonstrated by McCook and Mead. A comparison of results from all three locations demonstrates that local

TABLE 7. Descriptive statistics for soil moisture (volumetric water content) under rain-fed corn at three sites in NE for the period 1982-98.

\begin{tabular}{|c|c|c|c|c|c|c|}
\hline Station & Parameters & $\begin{array}{c}\text { Layer } 1 \\
0-2.5 \\
(\mathrm{~cm})\end{array}$ & $\begin{array}{c}\text { Layer } 2 \\
2.5-30.5 \\
(\mathrm{~cm})\end{array}$ & $\begin{array}{c}\text { Layer } 3 \\
30.5-61 \\
(\mathrm{~cm})\end{array}$ & $\begin{array}{c}\text { Layer } 4 \\
61-91.5 \\
(\mathrm{~cm})\end{array}$ & $\begin{array}{c}\text { Layer } 5 \\
91.5-122 \\
(\mathrm{~cm})\end{array}$ \\
\hline \multirow[t]{3}{*}{ McCook } & Mean & 0.24 & 0.29 & 0.21 & 0.16 & 0.15 \\
\hline & Std dev & 0.07 & 0.07 & 0.08 & 0.05 & 0.04 \\
\hline & $\mathrm{CV}$ & 29 & 24 & 38 & 31 & 26 \\
\hline \multirow[t]{3}{*}{ Clay Center } & Mean & 0.32 & 0.37 & 0.32 & 0.26 & 0.28 \\
\hline & Std dev & 0.07 & 0.07 & 0.07 & 0.07 & 0.06 \\
\hline & $\mathrm{CV}$ & 21 & 18 & 21 & 26 & 21 \\
\hline \multirow[t]{3}{*}{ Mead } & Mean & 0.46 & 0.53 & 0.41 & 0.30 & 0.24 \\
\hline & Std dev & 0.08 & 0.09 & 0.13 & 0.12 & 0.08 \\
\hline & $\mathrm{CV}$ & 17 & 16 & 31 & 40 & 33 \\
\hline
\end{tabular}


TABLE 8. Descriptive statistics for soil moisture (volumetric water content) under grass at three sites in NE for the period $1982-98$.

\begin{tabular}{|c|c|c|c|c|c|c|}
\hline Station & Parameters & $\begin{array}{c}\text { Layer } 1 \\
0-2.5 \\
(\mathrm{~cm})\end{array}$ & $\begin{array}{c}\text { Layer } 2 \\
2.5-30.5 \\
(\mathrm{~cm})\end{array}$ & $\begin{array}{c}\text { Layer } 3 \\
30.5-61 \\
(\mathrm{~cm})\end{array}$ & $\begin{array}{c}\text { Layer } 4 \\
61-91.5 \\
(\mathrm{~cm})\end{array}$ & $\begin{array}{c}\text { Layer } 5 \\
91.5-122 \\
(\mathrm{~cm})\end{array}$ \\
\hline \multirow[t]{3}{*}{ McCook } & Mean & 0.24 & 0.27 & 0.20 & 0.18 & 0.23 \\
\hline & Std dev & 0.07 & 0.08 & 0.07 & 0.05 & 0.03 \\
\hline & $\mathrm{CV}$ & 29 & 29 & 35 & 27 & 13 \\
\hline \multirow[t]{3}{*}{ Clay Center } & Mean & 0.31 & 0.35 & 0.32 & 0.28 & 0.32 \\
\hline & Std dev & 0.08 & 0.08 & 0.08 & 0.07 & 0.03 \\
\hline & $\mathrm{CV}$ & 25 & 22 & 25 & 25 & 9 \\
\hline \multirow[t]{3}{*}{ Mead } & Mean & 0.45 & 0.47 & 0.36 & 0.34 & 0.36 \\
\hline & Std dev & 0.10 & 0.14 & 0.14 & 0.10 & 0.05 \\
\hline & $\mathrm{CV}$ & 22 & 29 & 38 & 29 & 13 \\
\hline
\end{tabular}

hydroclimatic conditions, soils, and land use interact to control the degree of SM variability.

At the monthly scale SM variability at Mead, McCook, and Clay Center largely follows the patterns of the daily time scale. Month-to-month variability increases as the growing season progresses and decreases as plants approach physiological maturity (Figs. 19a,b). As expected, changes in SM variability from one month to the next are not as drastic as those at the daily scale, and overall the monthly variability is relatively
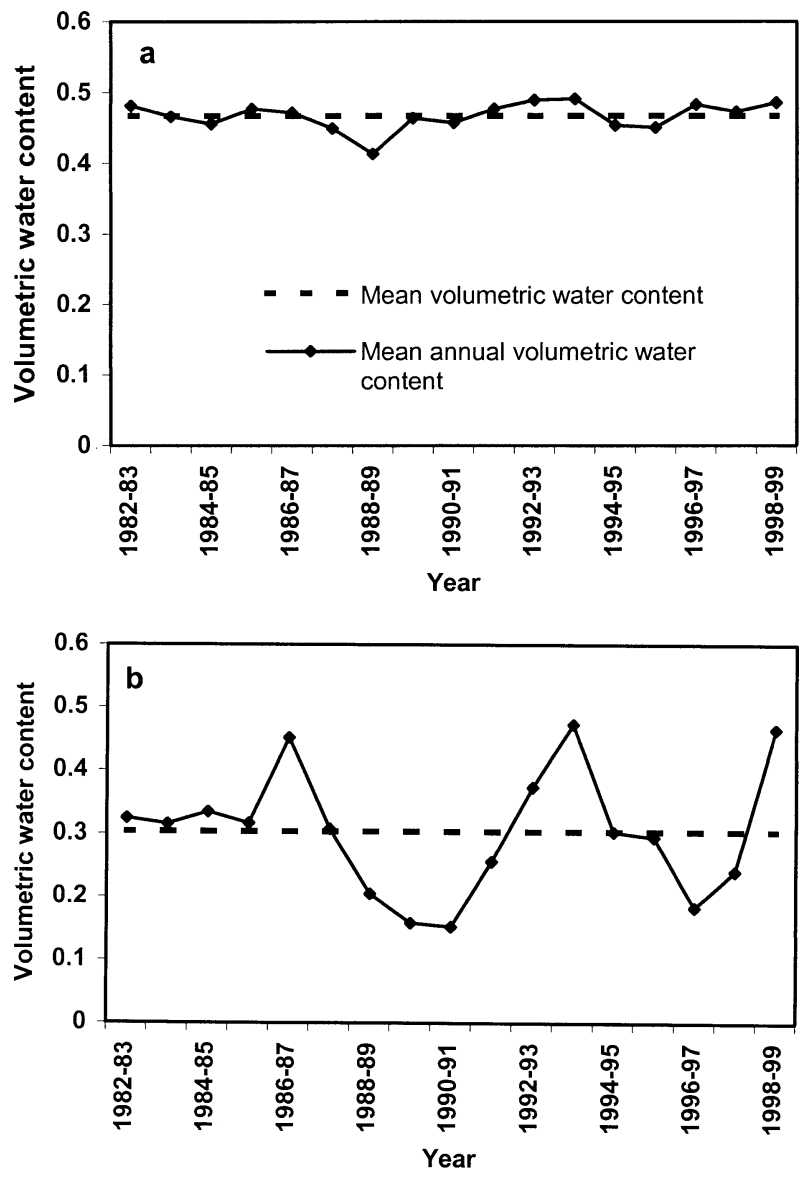

FIG. 15. Variation in mean daily annual volumetric water content for rain-fed corn at Mead, NE: (a) top and (b) fourth layers. "smooth" compared to the daily scale. Local hydroclimatic conditions, namely, wet or dry, reduced or increased, respectively, forcing of land use on SM variability at both daily and monthly time scales.

At the annual scale SM variability appears to be largely a function of climate-scale events. For example, at Mead the lowest variability for all land uses are in 199394 when precipitation excesses were widespread over the Mississippi basin resulting in the "flood of the century" (Fig. 20a). On the other hand, at McCook the highest annual variability for rain-fed corn and grass occurred in 1983-84 when there was an abnormally dry condition that continued into the following year (Fig. $20 b)$. The lowest variability at the annual time scale can be lower than the daily and monthly time scale, while the highest variability can be comparable to the highest variabilities of daily and monthly time scales. The analysis of annual-scale variability suggests that large-scale climate forcing is able to modify the forcings of land use and soils. It appears that excessively wet and dry conditions may reduce and enhance, respectively, SM variability. Therefore, the differences owing to land use are accentuated or diminished according to climate-scale events.

\section{Discussion and concluding remarks}

The present study investigated the daily SM climatology at three locations under three predominant land uses, namely, irrigated corn, rain-fed corn, and natural grass. Because these land uses of Nebraska are predominant, point-scale application provides insight into SM variations for the three land uses. The vertical scale of the applications is $1.2 \mathrm{~m}$. Large-scale modeling studies have yet to provide a clear understanding of these issues partly due to their spatiotemporal scale and due to the unavailability of input data at this scale. The estimation of SM through the vertical soil profile with input data describing the local soil-plant-hydrologic continuum at three locations offer us an opportunity to grasp the hydrologic process at the point scale. Because these pointscale estimations are representative of larger-scale land use and soil conditions, we speculate that the results could be insightful for parameterization of large-scale 

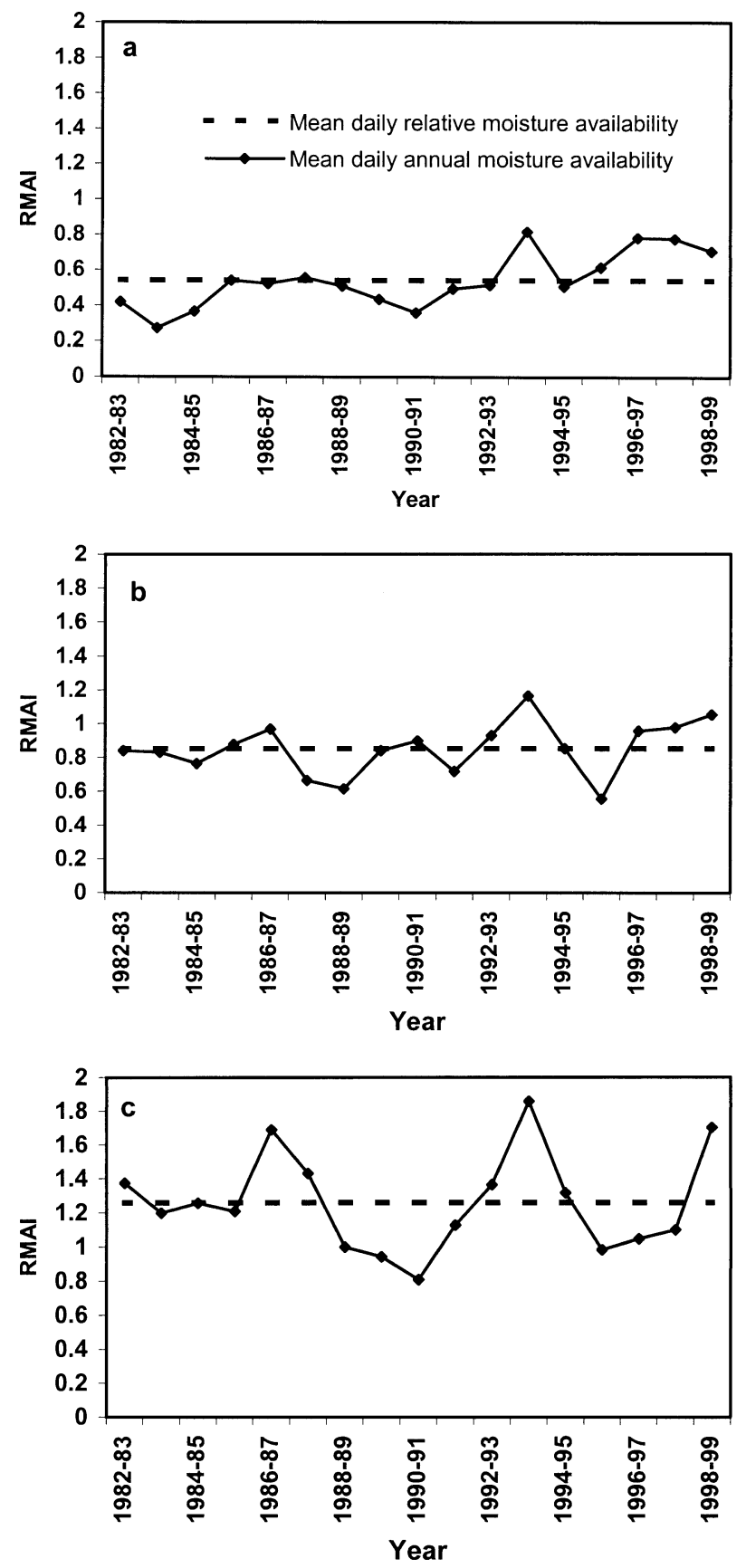

FIG. 16. Total RMAI for rain-fed corn at: (a) McCook, (b) Clay Center, and (c) Mead, NE.

SM calculation. Simultaneous estimates of SM for three land uses for each of the three locations and the analyses of simulated data provide a quantitative assessment of the response and impacts of predominant land cover and prevailing long-term hydroclimatic conditions. Due to large-scale modification of natural grasslands to agricultural land use in the Great Plains, it is essential that we investigate SM of crop lands along with grasslands.

As indicated above, this investigation provides a
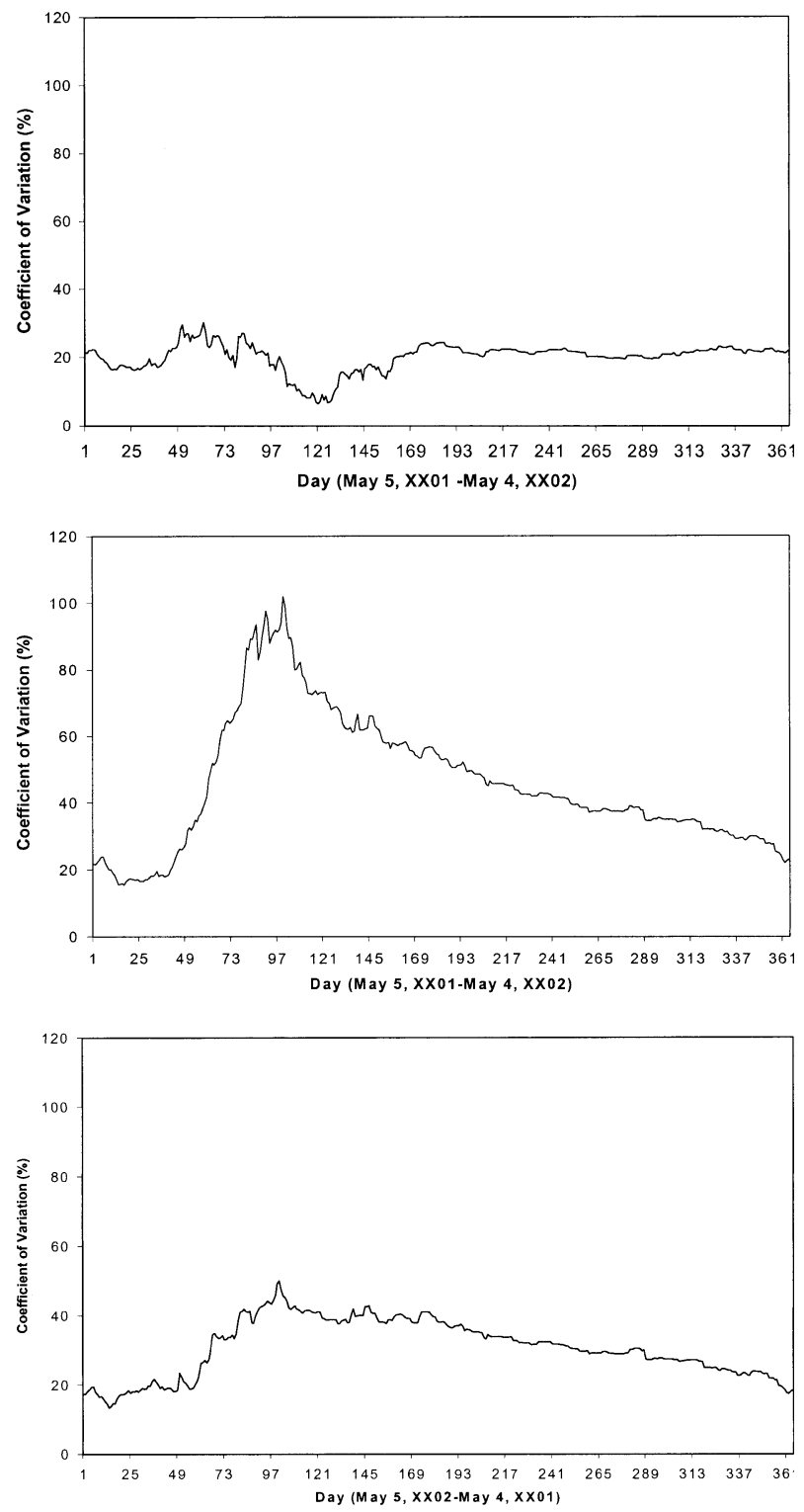

FIG. 17. SM variability in the root zone at daily time scale for McCook, NE: (a) irrigated corn, (b) rain-fed corn, and (c) grass. Day $1=5$ May.

quantitative assessment of daily SM dynamics and a mechanism to quantify what is known at a general level: SM begins depletion with the start of the growing season and reaches its lowest at the height of the crop growth, at the same time ET reaches a maximum, annual total evapotranspiration is higher for irrigated corn, and rainfed corn also evapotranspires at a higher rate compared to grass. Compared to grasslands, irrigated and rain-fed corn farming elevated and lowered plant available soil moisture through adding and mining water from the soil profile, respectively. Long-term averages suggest that lower soil layers (fourth and fifth) contain less water compared to upper soil layers (first and second) for all three land uses and at all three locations with variable 

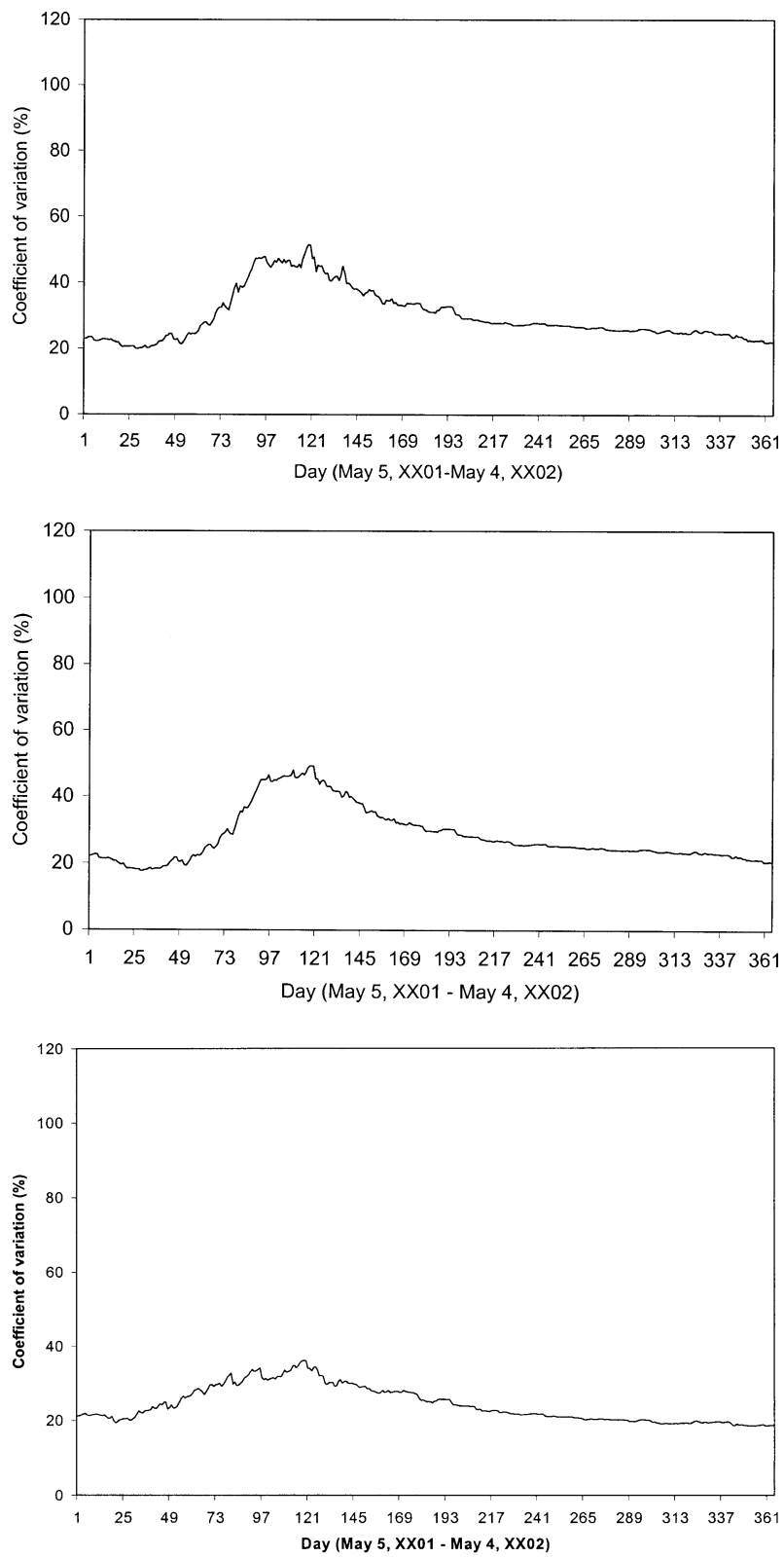

FIG. 18. SM variability in the root zone at daily time scale for Mead, NE: (a) irrigated corn, (b) rain-fed corn, and (c) grass. Day 1 $=5$ May.

moisture regimes. The type of vegetation affects depletion of SM at various depths via the differences in length of growing season and rooting depth. Unlike grass, SM variability in the top two layers under irrigated and rainfed corn was lower compared to the third-fifth layers. Interannual modulation of SM resulted in such variability (Figs. 15a,b).

Analysis of SM data at different temporal scales indicates that at the daily time scale, plant phenology plays an important role in modulation of SM variability. It is found that SM variability increases with progression of the growing season and decreases as the plants mature.
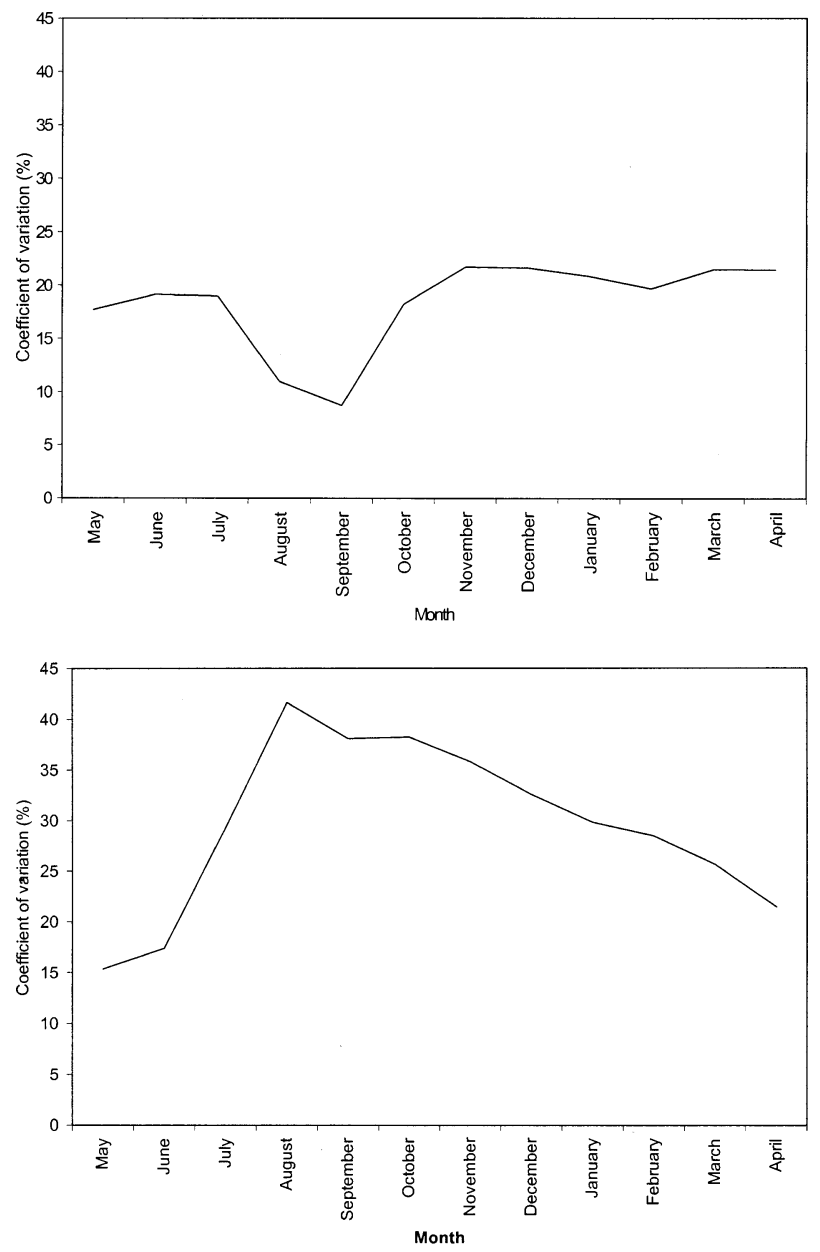

FIG. 19. SM variability in the root zone at monthly time scale for McCook, NE: (a) irrigated corn and (b) grass.

At the monthly time scale, SM variability also follows the pattern that resembles the variability of the daily time scale. However, as expected, changes in SM variability from one month to another are "smooth" as opposed to "step changes." It is found that land use and soils influence SM variability at daily and monthly time scales. The forcing of hydroclimatic condition (wet vs dry) is overwhelming. At all time scales, wet conditions reduced SM variability. At the annual time scale, forcing of large-scale climate modulation and associated wet or dry conditions influence SM variability. It is found that excessively wet conditions reduced SM variability and the differences between SM relative to land use, while extremely dry condition increased SM variability and forcing of land use. In other words, the influence of land use is dependent on the "normality" or "degree of anomaly" of climatic conditions.

The general pattern in SM depletion and recharge estimated by this model is comparable to Georgakakos et al. (1995) and Georgakakos and Bae (1994). This study presents a more detailed SM estimate by dividing the soil profile into five layers instead of one and two 

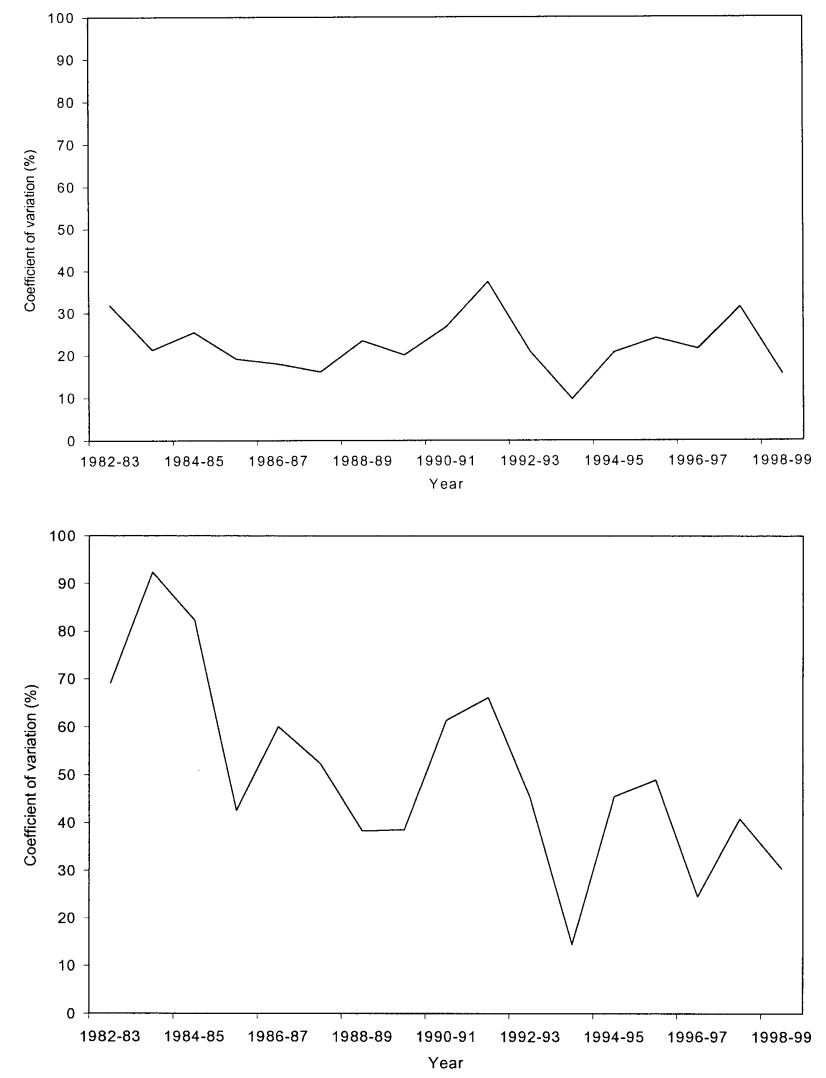

FIG. 20. SM variability in the root zone at annual time scale for (a) Mead, NE: grass and (b) McCook, NE: rain-fed corn.

layers, as presented by Durre et al. (2000) and Georgakakos et al. (1995), respectively. Therefore, the movement of soil water can be followed on scales not resolved by these previous models, giving us the opportunity to understand annual distribution of SM within the soil profile. Scott et al. (2000) reported that the extent of SM recharge in the root zone during winter in the semiarid southwestern United States may vary depending on precipitation amount. Our study also finds similar recharging during wintertime; obviously, the extent of recharge varies from year to year. Scott et al. (2000) identified large interannual variability in deeper root zone recharge. In our study, we have large interannual variability in SM at lower layers of all land uses except for the fifth soil layer under shallow-rooted grass. In other words, roots mine the water from the lower layers and, over a long period of time, SM variability is higher in the deeper layers despite different climate and soil regimes. In addition, larger amplitudes of root zone total SM under irrigated and rain-fed corn indicate their vulnerability to current hydroclimatic conditions.

The results of this study have raised a number of critical questions related to forcings of land use and soils on SM variability as they interact with climate. What is the threshold anomaly that reduces or enhances SM variability? What is the variation in this threshold as land use and soils changes? The authors suggest that additional research needs to be conducted to quantify these threshold conditions for predominant land uses. In our opinion, findings can be important to diagnose modeling results and improve predictive skills.

This study demonstrated the changes in the magnitude of variability of SM under different land uses at multitemporal scales. An important question is how can we transfer this knowledge to mesoscale and climate models. In other words, we need to develop methods to incorporate these near-surface variabilities in the models. In addition, how sensitive is the system to these SM variabilities? How much modulation of weather and climate can be expected at various spatial scales by these variabilities? This brings up the question of feedback between SM and the atmosphere at multiple spatiotemporal scales. Are these issues adequately addressed during model formulation? Are these issues being explicitly addressed during current modeling activities? Wang and Kumar (1998), Dirmeyer (1999, 2000), and Huang et al. (1996) noted that SM can be an important predictor of surface temperature and precipitation. Thus, we suggest that specific modeling studies should be undertaken to determine SM variability at multitemporal scales under heterogeneous land use, and their impacts on weather and climate and their predictability. Such studies would hopefully determine the sensitivity of the atmosphere to SM variability and, also, the behavior of the mesoscale and climate models.

This study has demonstrated the potential future use of the RH soil water balance model to estimate SM of the past at various depths and under a number of land covers. We plan to produce a gridded SM database from point simulations and to use these data to study land memory processes in the NGP, water cycling, and variations of SM at various spatiotemporal scales. It is also suggested that this SM data can be used further for various mesoscale and climate modeling studies. In our case, there are advantages of gridding from point data, as opposed to cell-based modeling. We have already collected these data for $150+$ application sites and are prepared to collect data for an additional 50 locations. These sites also represent predominant soil types of the local county. The soils database for cooperative weatherrecording locations is also under way. At the same time, detailed cell-by-cell data on soil physical properties, as required by a grid-based model, are not available. Based on the spatial density of the model application sites and the detailed representation of root zone soil characteristics for predominant soils, we have concluded that the land surface condition of the study area has been described in detail (horizontally and vertically), correctly, for the RH model applications. Therefore, gridding from point data will provide sufficiently accurate estimates of SM and ET.

In related studies, methods were developed for estimating the solar radiation and relative humidity of the past for the NGP (Mahmood and Hubbard 2002b; Hub- 
bard et al. 2002). Availability of soil and weather data with reliable solar and relative humidity estimates will permit us in the near future to estimate SM of the past for a large number of locations in the NGP. These locations will include automated and cooperative weatherobserving sites and, thus, will provide a higher spatial density for SM model applications. The SM data produced from this work will be invaluable for future investigations in the areas of hydrology and land-atmosphere interactions.

We believe the results presented in this paper indicate the importance of developing reliable parameterization of soil water balance in various climate models. The grasslands of the North American Great Plains and other parts of the world were modified rapidly and vastly over the last century due to human economic activities, including farming. Therefore, it is imperative that we understand the temporal changes in the soil water condition in the soil profile under dominant land uses over large regions, along with natural conditions. This type of study will improve our overall understanding of soil water distribution within the soil profile over a time period.

Acknowledgments. The authors would like to thank Drs. Charles A. Francis and David A. Wedin, the anonymous reviewers, and the editors for their valuable comments and suggestions. Assistance provided by Sebastien O. Korner during preparation of Fig. 1 is much appreciated. This paper has a University of Nebraska Journal Series No. 13534.

\section{REFERENCES}

Black, T. L., 1994: The new NMC Mesoscale Eta model: Description and forecast examples. Wea. Forecasting, 9, 265-278.

Camargo, M. B. P., 1993: Determination of the water balance components and drought sensitivity indices for a sorghum crop. Ph.D. dissertation, University of Nebraska at Lincoln, $131 \mathrm{pp}$.

—, K. G. Hubbard, and F. Flores-Mendoza, 1994: Test of a soil water assessment model for a sorghum crop under different irrigation treatments. Bragantia Campinas, 53, 95-105.

Campbell, G. S., 1985: Soil Physics with BASIC. Elsevier, 150 pp.

Chen, F., and K. Mitchell, 1999: Using GEWEX/ISLSCP forcing data to simulate global soil moisture fields and hydrological cycle for 1987-1988. J. Meteor. Soc. Japan, 77, 167-182.

Chen, T. H., A. Henderson-Sellers, P. C. D. Milly, A. J. Pitman, and A. C. Beljaars, 1997: Cabauw experimental results from the Project for Intercomparison of Land-Surface Parameterization Schemes. J. Climate, 10, 1194-1215.

Cherkauer, K. A., and D. P. Lettenmaier, 1999: Hydrologic effects of frozen soils in the upper Mississippi River basin. J. Geophys. Res., 104, 19 599-19610.

Crawford, T. M., D. J. Stensrud, T. N. Carlson, and W. J. Capehart, 2000: Using a soil hydrology model to obtain regionally averaged soil moisture values. J. Hydrometeor., 1, 353-363.

Delworth, T., and S. Manabe, 1988: The influence of potential evaporation on the variability of simulated soil wetness and climate. J. Climate, 1, 523-547.

Dirmeyer, P. A., 1999: Assessing GCM sensitivity to soil wetness using GSWP data. J. Meteor. Soc. Japan, 77, 367-385.

$\ldots$, 2000: Using a global soil wetness dataset to improve seasonal climate simulation. J. Climate, 13, 2900-2922.
_ A. J. Dolman, and N. Sato, 1999: The pilot phase of the Global Soil Wetness Project. Bull. Amer. Meteor. Soc., 80, 851-878.

Dudhia, J., 1993: A nonhydrostatic version of the Penn State-NCAR Mesoscale Model: Validation tests and simulation of an Atlantic cyclone and cold front. Mon. Wea. Rev., 121, 1493-1513.

Durre, I., J. M. Wallace, and D. P. Lattenmaier, 2000: Dependence of extreme daily maximum temperature on antecedent soil moisture in the contiguous United States during summer. J. Climate, 13, 2641-2651.

Entin, J. K., A. Robock, K. Y. Vinnikov, V. Zabelin, S. Liu, A. Namkhai, and T. Adyasuren, 1999: Evaluation of Global Soil Wetness Project soil moisture simulations. J. Meteor. Soc. Japan, 77, 183-198.

,,--- , and S. E. Hollinger, 2000: Temporal and spatial scales of observed soil moisture variations in the extratropics. J. Geophys. Res., 105, $11865-11877$.

GCIP, 2000: GEWEX Americas Prediction Project (GAPP): Science plan and implementation strategy: Draft. GCIP, 160 pp.

Georgakakos, K. P., and D.-H. Bae, 1994: Climatic variability of soil water in the American Midwest: Part 2. Spatio-temporal analyses. J. Hydrol., 162, 379-390.

,$- \ldots$, and D. R. Cayan, 1995: Hydroclimatology of continental watersheds. 1. Temporal analyses. Water Resour. Res., 31, 655675.

Hollinger, S. E., and S. A. Isard, 1994: A soil moisture climatology of Illinois. J. Climate, 7, 822-833.

Hong, S.-Y., and H.-L. Pan, 2000: Impact of soil moisture anomalies on seasonal, summertime circulation over North America in a regional climate model. J. Geophys. Res., 105, 29 625-29 634.

Huang, J., H. M. Van den Dool, and K. P. Georgakakos, 1996: Analysis of model-calculated soil moisture over the United States (1931-1993) and applications to long-range temperature forecasts. J. Climate, 9, 1350-1362.

Hubbard, K. G., R. Mahmood, and C. Carlson, 2002: Estimating dew point temperature for the northern Great Plains, USA. Agron. J., 95, 323-328.

Kincaid, D. C., and D. F. Heerman, 1974: Scheduling irrigations using a programmable calculator. USDA Publication USDA-ARS-NC12 .

Leese, J. A., 2000: GEWEX/BAHC International Workshop on Soil Moisture Monitoring, Analysis and Prediction for Hydrometeorological and Hydroclimatological Applications. Workshop Summary Rep., IGPO Doc. 35, 42 pp.

__ T. Jackson, A. Pitman, and P. Dirmeyer, 2001: GEWEX/BAHC International Workshop on Soil Moisture Monitoring, Analysis, and Prediction for Hydrometeorological and Hydroclimatological Applications. Bull. Amer. Meteor. Soc., 82, 1423-1430.

Legates, D. R., and G. J. McCabe Jr., 1999: Evaluating the use of "goodness-of-fit" measures in hydrologic and hydroclimatic model validation. Water Resour. Res., 35, 233-241.

Liang, X., E. F. Wood, and D. P. Lettenmaier, 1996: Surface soil moisture parameterization of the VIC-2L model: Evaluation and modification. Global Planet. Change, 13, 195-206.

—_ and Coauthors, 1998: The project for intercomparison of landsurface parameterization schemes (PILPS) phase 2(c) Red-Arkansas river basin experiment: 2 . Spatial and temporal analysis of energy fluxes. Global Planet. Change, 19, 137-159.

Lohmann, D., and Coauthors, 1998: The project for intercomparison of land-surface parameterization schemes (PILPS) phase 2(c) Red-Arkansas river basin experiment: 3. Spatial and temporal analysis of water fluxes. Global Planet. Change, 19, 161-179.

Mahmood, R., and K. G. Hubbard, 2002a: Anthropogenic land use change in the North American tall grass-short grass transition and modification of near surface hydrologic cycle. Climate Res., 21, 83-90.

- and _ 2002b: Effect of time of temperature observation and estimation of daily solar radiation for the northern Great Plains, USA. Agron. J., 94, 723-733.

, and — 2003: Simulating sensitivity of soil moisture and 
evapotranspiration under heterogeneous soils and land uses. $J$. Hydrol., 280, 72-90.

- - - , and Q. Hou, 2001: Soil moisture monitoring and modeling in the Great Plains. Automated Weather Stations for Applications in Agriculture and Water Resources Management: Current Use and Future Perspectives, K. G. Hubbard and M. V. K. Sivakumar, Eds., High Plains Climate Center and World Meteorological Organization, 163-171.

,$--\ldots$, and C. Carlson, 2002: Land use change and modification of near-surface thermal records in the northern Great Plains. Bull. Amer. Meteor. Soc., 83, 504.

Matsuyama, H., T. Nishimura, and N. Sato, 1999: Validation of the atmospheric forcings of ISLSCP initaitive I CD-ROM and outputs from the JMA-SiB using FIFE observations. J. Meteor. Soc. Japan, 77, 199-215.

Maurer, E. P., and D. P. Lettenmaier, 2003: Predictability of seasonal runoff in the Mississippi River basin. J. Geophys. Res., 108, 8607, doi:10.1029/2002JD002555.

— - A. W. Wood, J. C. Adam, and D. P. Lettenmaier, 2002: A longterm hydrologically based dataset of land surface fluxes and states for the conterminous United States. J. Climate, 15, 32373251.

McCuen, R. H., 1982: A Guide to Hydrologic Analysis Using SCS Methods. Prentice-Hall, 145 pp.

Meyer, S. J., K. G. Hubbard, and D. A. Wilhite, 1993a: A cropspecific drought index for corn: I. Model development and validation. Agron. J., 85, 388-395.

,-- , and $-1993 \mathrm{~b}$ : A crop-specific drought index for corn: II. Application in drought monitoring and assessment. Agron. J., 85, 396-399.

Mitchell, K., and Coauthors, 2000: The collaborative GCIP Land Data Assimilation (LDAS) project and supportive NCEP uncoupled land surface modeling initiatives. Preprints, 15th Conf. on Hydrology, Long Beach, CA, Amer. Meteor. Soc., 1-4.

Morill, J. C., R. E. Dickinson, and A. N. Hahmann, 1999: Sensitivity of a land surface model to the diurnal distribution of downward longwave radiation. J. Meteor. Soc. Japan, 77, 265-279.

Nijssen, B., R. Schnur, and D. P. Lettenmaier, 2001: Global retrospective estimation of soil moisture using the variable infiltration capacity land surface model, 1980-93. J. Climate, 14, 17901808.

Penman, H. L., 1948: Natural evapotranspiration from open water, bare soil and grass. Proc. Roy. Soc. London, A193, 120-145.

Pitman, A. J., M. Zhao, and C. E. Desborough, 1999: Investigating the sensitivity of a land surface scheme's simulation of soil wetness and evaporation to spatial and temporal leaf area index variability within the Global Soil Wetness Project. J. Meteor. Soc. Japan, 77, 281-290.

Qiu, Y., B. Fu, J. Wang, and L. Chen, 2001: Soil moisture variation in relation to topography and land use in a hillslope catchment of the Loess Plateu, China. J. Hydrol., 240, 243-263.

Qu, W., and Coauthors, 1998: Sensitivity of latent heat flux from
PILPS land-surface schemes to perturbations of surface air temperature. J. Atmos. Sci., 55, 1909-1927.

Robinson, J. M., and K. G. Hubbard, 1990: Soil water assessment model for several crops in the high plains. Agron. J., 82, 11411148 .

Robock, A., K. Y. Vinnikov, C. A. Schlosser, N. A. Speranskaya, and Y. Xue, 1995: Use of mid-latitude soil moisture simulations with biosphere and bucket models. J. Climate, 8, 15-35.

- ——, and ——, 1997: Reply. J. Climate, 10, 377-379.

, C. A. Schlosser, K. Y. Vinnikov, N. A. Speranskaya, and J. K. Entin, 1998: Evaluation of AMIP soil moisture simulations. Global Planet. Change, 19, 181-208.

_, K. Y. Vinnikov, G. Srinivasan, J. K. Entin, S. E. Hollinger, N. A. Speranskaya, S. Liu, and A. Namkhai, 2000: The global soil moisture data bank. Bull. Amer. Meteor. Soc., 81, 1281-1299.

Schlosser, C. A., A. G. Slater, A. Robock, K. Y. Vinnikov, N. A. Speranskaya, and Y. Xue, 1997: 18-year land-surface hydrology model simulations for a midlatitude grassland catchment in Valdai, Russia. Mon. Wea. Rev., 125, 3279-3296.

_ drology at Valdai, Russia: PILPS phase 2(d). Mon. Wea. Rev., 128, 301-321.

Schmugge, T. J., T. J. Jackson, and H. L. McKim, 1980: Survey of methods of soil moisture determination. Water Resour. Res., 16, 961-979.

Scott, R. L., W. J. Shuttleworth, T. O. Keefer, and A. W. Warrick, 2000: Modeling multi-year observations of soil moisture recharge in the semiarid American Southwest. Water Resour. Res., 36, 2233-2247.

Srinivasan, G., A. Robock, J. K. Entin, L. Luo, K. Y. Vinnikov, P. Viterbo, and Participating AMIP Modeling Groups, 2000: Soil moisture simulations in revised AMIP models. J. Geophys. Res., 105, 26 635-26 644.

United States Global Change Research Program (USGCRP), 2001: A plan for a new science initiative on the global water cycle. USGCRP Report, 118 pp.

Vinnikov, K. Ya., and I. B. Yeserkepova, 1991: Soil moisture: Empirical data and model results. J. Climate, 4, 66-79.

Wang, W., and A. Kumar, 1998: A GCM assessment of atmospheric seasonal predictability associated with soil moisture anomalies over North America. J. Geophys. Res., 103, 28 637-28 646.

Willmott, C. J., 1981: On the validation of models. Phys. Geogr., 2, 184-194.

Wittrock, V., and E. A. Ripley, 1999: The predictability of autumn soil moisture levels on the Canadian Prairies. Int. J. Climatol., 19, 271-289.

Wood, E. F., and Coauthors, 1998: The project for intercomparison of land-surface parameterization schemes (PILPS) phase 2(c) Red-Arkansas river basin experiment: 1. Experiment description and summary intercomparisons. Global Planet. Change, 19, $115-135$.

Zhang, C., D. A. Dazlich, and D. A. Randall, 1999: Simulations of soil moisture and surface water balance using the simple biosphere model 2. J. Meteor. Soc. Japan, 77, 217-234. 